\title{
Regenerative Skin Wound Healing in Mammals: State-of-the-Art on Growth Factor and Stem Cell Based Treatments
}

\author{
Bizunesh M. Borena ${ }^{a, b}$ Ann Martens ${ }^{c}$ Sarah Y. Broeckx ${ }^{d, e}$ Evelyne Meyer ${ }^{f}$ \\ Koen Chiersg Luc Duchateau ${ }^{a}$ Jan H. Spaas ${ }^{d, e}$
}

${ }^{a}$ Department of Comparative Physiology and Biometrics, Faculty of Veterinary Medicine, Ghent University, Merelbeke, Belgium; 'bepartment of Veterinary Laboratory, College of Agriculture and Veterinary Science, Ambo University, Ambo, Ethiopia; 'Department of Surgery and Anesthesiology of Domestic Animals, Faculty of Veterinary Medicine, Ghent University, Merelbeke, Belgium; dGlobal Stem cell Technology, ANACURA group, Evergem, Belgium, ePell Cell Medicals, ANACURA group, Evergem, Belgium; fDepartment of Pharmacology, Toxicology and Biochemistry, Faculty of Veterinary Medicine, Ghent University, Merelbeke, Belgium; ' Department of Pathology, Bacteriology and Poultry Diseases, Faculty of Veterinary Medicine, Ghent University, Merelbeke, Belgium

\section{Key Words}

Skin $\cdot$ Wound healing $•$ Growth factor $\cdot$ Stem cell

\begin{abstract}
Mammal skin has a crucial function in several life-preserving processes such as hydration, protection against chemicals and pathogens, initialization of vitamin D synthesis, excretion and heat regulation. Severe damage of the skin may therefore be life-threatening. Skin wound repair is a multiphased, yet well-orchestrated process including the interaction of various cell types, growth factors and cytokines aiming at closure of the skin and preferably resulting in tissue repair. Regardless various therapeutic modalities targeting at enhancing wound healing, the development of novel approaches for this pathology remains a clinical challenge. The time-consuming conservative wound management is mainly restricted to wound repair rather than restitution of the tissue integrity (the so-called "restitutio ad integrum"). Therefore, there is a continued search towards more efficacious wound therapies to reduce health care burden, provide patients with long-term relief and ultimately scarless wound healing. Recent in vivo and in vitro studies on the use of skin wound regenerative therapies provide encouraging results, but more protracted studies will have to determine whether the effect of observed effects are clinically significant and whether regeneration rather than repair can be achieved. For all the aforementioned reasons, this article reviews the emerging field of regenerative skin wound healing in mammals with particular emphasis on growth factor- and stem cell-based therapies.
\end{abstract}

Copyright (c) 2015 S. Karger AG, Basel

Jan H. Spaas

KARGER 125
Head R\&D Stem Cell Platform GST-ANACURA

Noorwegenstraat 4, 9940 Evergem (Belgium)

Tel. +32 925715 02, Fax +32 925715 38, E-Mail jan.spaas@anacura.com 


\section{Introduction}

Comprising $10 \%$ of the total body mass, the skin is the largest organ of vertebrates and is crucial for defense as well as survival. Each injury induces loss of the integrity of the skin resulting in functional imbalance, possibly accompanied by disability or even death [1]. Skin injury initiates mechanisms to limit damage and subsequently induce repair. Both phenomena cover a complex cascade of temporal and spatial events that are required for tissue homeostasis. These events include induction and resolution of inflammation on the one hand, and the formation and remodeling of tissue on the other hand with the goal to achieve complete reconstruction of the wounded area [2]. Repair of skin wounds in adults is commonly achieved with fibrosis resulting in a scar which is more fragile than the original skin because it consists of disorganized extracellular matrix (ECM) [3, 4]. This repair process differs from regeneration where the resulting tissue is almost indistinguishable from the original tissue $[4,5]$. In this context it should be mentioned that in mammals the fetal skin regenerates flawlessly in contrast to adult skin. The underlying regulation of this switch in repair mechanism potential during mammalian development is not yet completely understood [6].

Full-thickness skin wounds may result in extensive damage to the different skin structures and the underlying tissues. This damage compromises the homeostatic mechanisms involved in spontaneous healing and therefore clinical intervention is often needed. The primary aim of clinical skin wound treatment is to promote rapid wound repair with functional and aesthetical satisfactory scar tissue formation [7].

Today, skin wound therapies are categorized as either conventional or regenerative. Conventional skin wound management includes debridement of necrotized tissue followed by the topical use of different types of wound dressings thus ensuring sufficient tissue perfusion, limiting wound pressure and reducing infection. Besides, any underlying health problem that could alter the healing process should be controlled [7]. Wounds healed by conventional therapy are characterized by scar formation with cosmetic and possible functional impairment. For example, skin scars are more sensitive to ultraviolet radiation, and lack sweat glands or hair follicles [8]. Regenerative skin wound therapy is a novel and rapidly developing field of biomedical research that aims to promote wound healing and to restore the damaged cells and diseased skin tissue without scar formation. Since quality care is a crucial aspect of wound healing [9], regenerative strategies should not be considered as a substitute for certain indispensable conventional treatments (e.g. debridement) but should be considered complementary. Therefore, in the present review information has been gathered on preclinical and clinical studies regarding regenerative therapies for mammal skin wound management with particular emphasis on growth factor- and stem cell-based therapies.

\section{Literature search}

The standard research databases like PubMed and Web of Science between January 1955 and December 2014 and the Google Scholar search engine were consulted for collection of full papers and abstracts.

\section{Mammalian skin and wound healing}

Adult mammalian skin anatomy and physiology

Mammalian skin is the largest organ of the adult body and consists of several layers: (i) the superficial epidermis, (ii) the intermediate dermis $[1,10]$ and (iii) the hypodermis, and is supported by a matrix of loose connective tissue [10] (Fig. 1). 
Noteworthy, there are significant differences in the anatomy and physiology of each skin layer between species [11]. Consequently, these differences result in differences in wound healing [12]. For instance, in animals with a more "loose" skin such as rats and mice, healing occurs very rapidly as a result of wound contraction initiated by the musculus panniculus carnosus in their subcutaneous tissues. On the other hand, in "tight-skinned" species such as human and porcine, which lack this muscle, wound contraction is not rapid thus skin heals mainly through re-epithelialization $[13,14]$. Striking differences in wound healing can even be exhibited within the same species, and have been observed at gross, cellular and molecular level. For example an earlier start and termination of wound inflammation leading to earlier wound contraction and epithelialization was detected in ponies in comparison to horses $[13,15]$. This difference in wound healing was attributed to a different local inflammatory response, where leukocytes in ponies were found to produce more inflammatory mediators. This resulted in an enhanced local defense, earlier cellular debridement, earlier transition to the repair phase and increased wound contraction [15].

Mammalian epidermis, which is a terminally differentiated and stratified squamous epithelium, consists of 4 to 5 sublayers (Fig. 1). The barrier function of intact epidermis depends on the quality of the present cells and the surrounding matrix [16, 17]. Epidermis and dermis are physically separated by the basement membrane or basal lamina, a highly specialized ECM structure, which provides a stabilizing and dynamic interface [18]. Besides providing structural adhesion of both skin structures, the basement membrane has a gatekeeping function tightly regulating diffusion of cells [19] and bioactive molecules [19, 20]. On the other hand, it can bind several cytokines and growth factors, indicating a "reservoir" function for a controlled release during physiologic remodeling and repair after injury [19].

The dermis is located below the epidermis and is composed of papillary and reticular layers (Fig. 1). The upper papillary layer edges into the epidermis across the basement membrane and nourishes it. This layer consists of (i) cellular components, including fibroblasts, mast cells, macrophages and dermal dendrocytes and (ii) ECM components namely stromal components (e.g. collagen and elastic fibers) and matrix component (glycoproteins, proteoglycans, cell regulating macromolecules etc.) [21]. The lower reticular

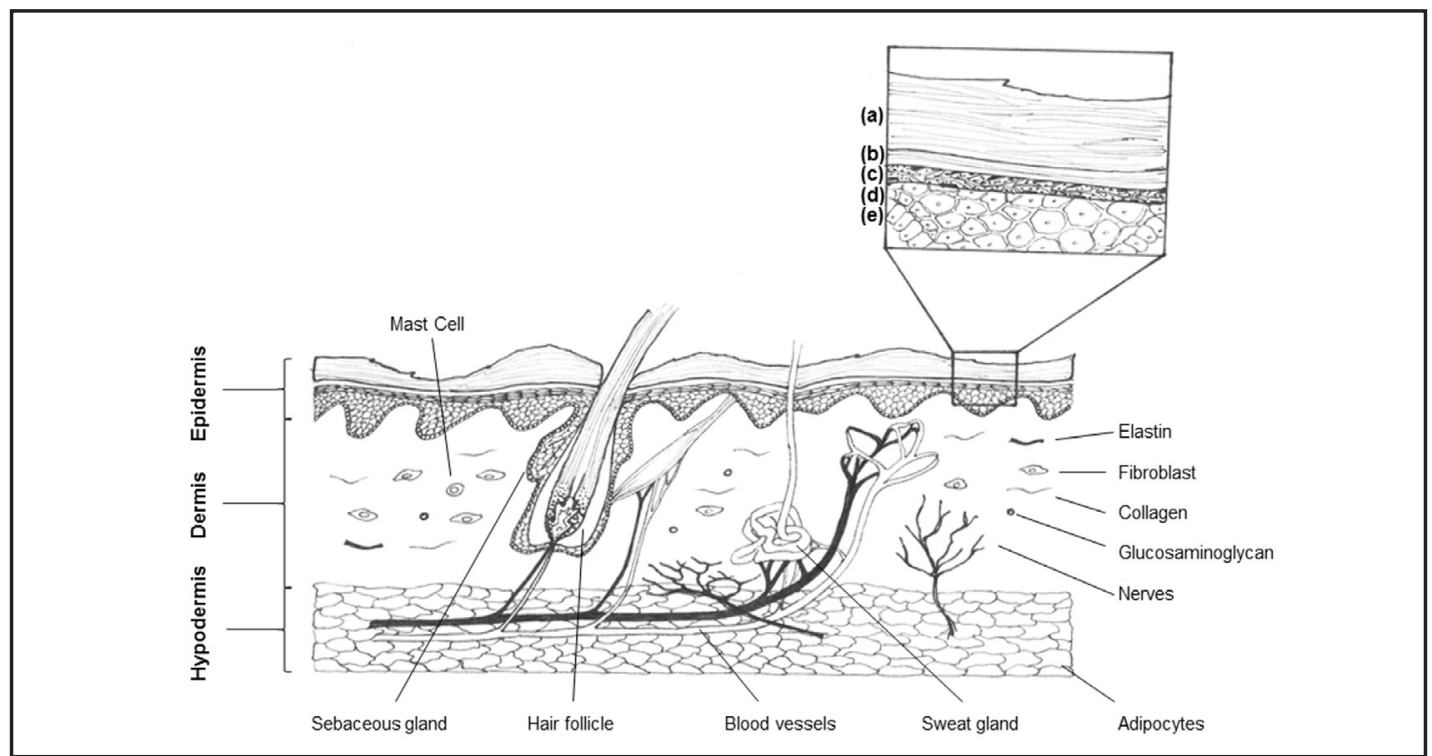

Fig. 1. Schematic representation of mammalian skin structure and its cell populations. The skin contains three layers: epidermis, dermis and hypodermis. The epidermis is a stratified epithelium composed of 4 to 5 layers: stratum corneum (a), stratum lucidum (b), stratum granulosum (c), stratum spinosum (d) and stratum basale (e). Other structures in the skin include the hair (f), sweat glands (g), sebaceous glands (h), hair follicles (i), nerves (j) and blood vessels (k). 
layer is characterized by an ECM containing collagen, elastic fibers and fibroblasts [6]. The dermis is vascularized, innervated and invaded by epidermal appendages. The hypodermis is situated underneath the dermis and mainly consists of adipose tissue and blood vessels (Fig. 1). These structures ensure the lifesaving mechanical and thermoregulatory characteristics of the skin [1]. The epidermis and its appendages (e.g. hair follicles, sebaceous glands, sweat glands and nails) are derived embryologically from the prospective epidermal ectoderm and neural crest cells, which are also ectodermal in origin. Nevertheless, the skin appendages have their roots in the dermis or even in the hypodermis, both of which are derived from embryonic mesoderm [6].

Every disturbance of the normal anatomic organization of a tissue resulting in function reduction can be described as a wound [22]. Skin wound healing relies on a complex dynamic process which involves interaction of multiple cell types, growth factors, cytokines and chemokines [7,23]. Dysfunction of this mechanism might result in chronic, non-healing wounds or excessive granulation tissue formation presented as keloids and hypertrophic scars [24]. However, there are reports which indicate that even when this balance is disrupted, absent cells or mediators can be compensated [25].

Adult skin wounds may heal by repair or regeneration and there is a clear difference between both types of healing. Repair consists of a physiologic adjustment after function disruption in order to create continuity without aiming at reconstitution of the original tissue (Fig. 2). Regeneration on the other hand, aims at rebuilding injured tissue with an 'exact' copy, in order to restore tissue morphology as well as functionality. It should be remarked that the adult mammalian skin does not regenerate spontaneously, yet heals with scar formation (a typical feature of the repair process).

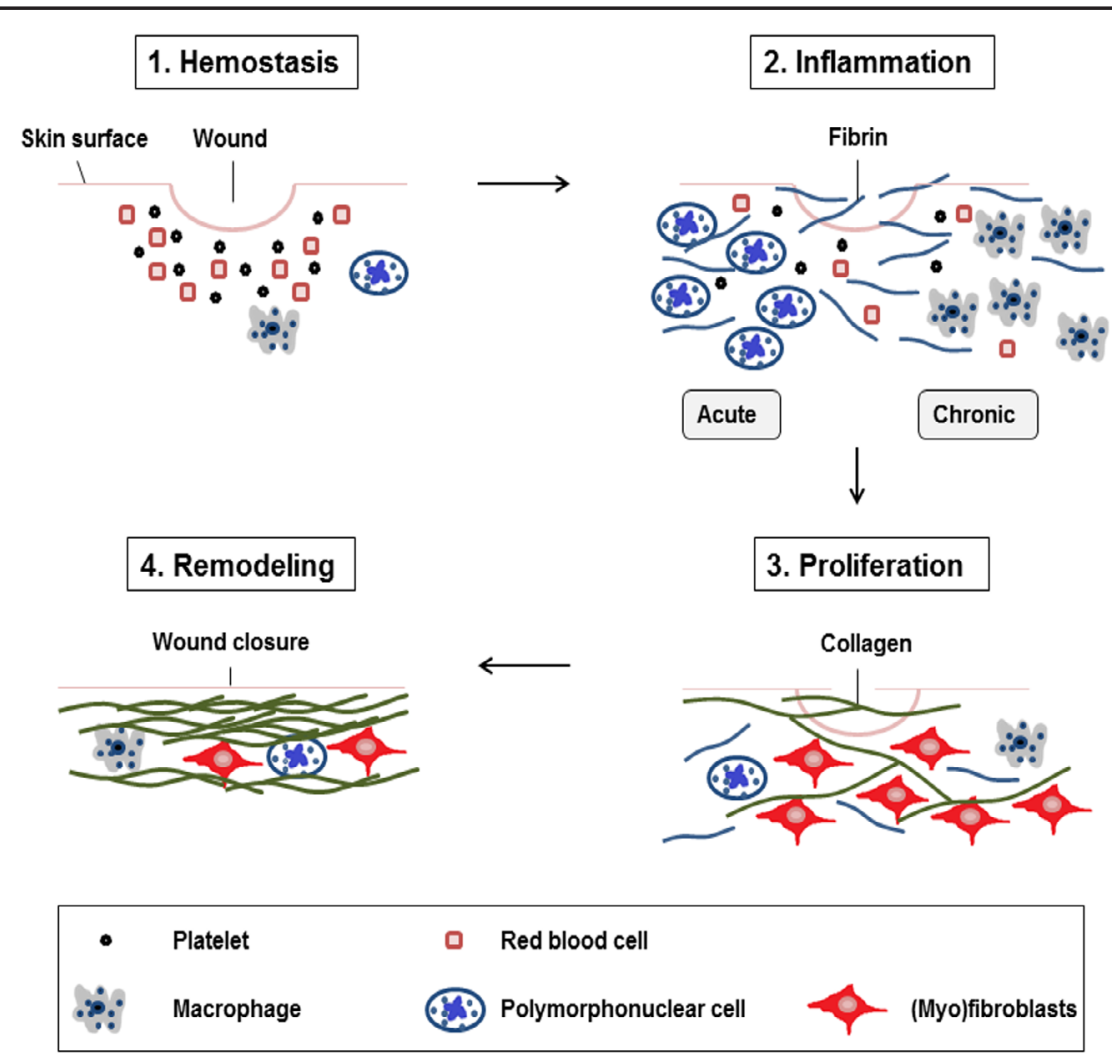

Fig. 2. Schematic representation of the basic steps of cutaneous wound healing. Following injury wound healing proceeds in four interrelated dynamic phases which overlap in time. 
Mammalian embryo as a model for scarless wound healing

Humans and other mammal adults have a limited capacity to regenerate and restore their tissues and organs. This can be obtained through the attraction of somatic stem cells located in a niche or by inducing differentiated cells to proliferate [26]. Accordingly, the wound healing process in adult mammals is imperfect and less restorative than in the juvenile or in the embryo [6]. Indeed, skin wounds in early mammalian embryos have the ability to repair without scar formation and with complete restitution of the physiological skin architecture [27]. There are many discrepancies between embryonic and adult wound healing. Although this is mainly attributed to the tissue development itself, fetal scarless wound healing mechanisms are intrinsically different. In fact, fetal wounds heal with a distinctly reduced inflammatory reaction [28], a faster production of ECM components (fibronectin and tenascin), a high hyaluronic acid content and changed profiles of growth factor expression. In an embryonic wound site, the levels of transforming growth factor (TGF)- $\beta 1$ and $-\beta 2$ are lower while TGF- $\beta 3$ is higher than in an adult wound site [29]. Another essential difference between fetus and adult concerns wound contraction and epithelialization. Fetal wounds close through an actin cable [30], whereas adult wound closure involves active movement of connective tissue and epidermis in order to bring two wounded edges in close proximity to allow the epidermis to migrate and cover the exposed connective tissue [31]. In contrast, some other vertebrate species like amphibians have extensive regenerative capacities that in certain cases stretch as far as replacing a complete limb [32,33].

\section{Role of stem cells in wound healing}

Most epithelia self-renew through a mechanism called "tissue homeostasis", in which the number of cell divisions is in balance with the number of cells lost [34]. Tissue homeostasis is guaranteed by stem cells (SCs) present within specialized microenvironments, the so-called niches. Each niche is designed to facilitate the repair or regeneration requirements of its tissue [35]. The skin epidermis and its appendages harbor spatially distinct SC niches [36] (Fig. 1). For instance, bulge stem cells which are designated to form hair follicles, have the ability to temporary produce wound epidermis as an "emergency" strategy [37]. In marked contrast, a later experiment by Levy et al [38] reported that follicular progenitors different from bulge SCs exist and may permanently transform into interfollicular epidermis SCs after wound induction in mice.

Adult SCs are considered to replace lost cells and are therefore identified as central players in tissue regeneration. They deliver daughter cells to renew the lesioned tissues by differentiation and/or by releasing paracrine factors to attract progenitor cells [39]. When a SC compartment is being inflicted, other SCs can be mobilized to enhance lesion repair. However, the fate of epithelial cells might also adapt during wound regeneration. Unipotent progenitors have the capacity to obtain multipotency, whereas in other cases adult epithelial cells revert to a SC-like state [36].

\section{Regenerative therapies for skin wound management}

Regenerative medicine is defined as a novel and fast growing field of biomedical research that focuses on replacing, restoring and regenerating damaged cells, tissues and organs [40]. This can potentially be accomplished using the process of dedifferentiation (which involves terminally differentiated cells reverting back to a less differentiated stage), transdifferentiation (a processes which takes dedifferentiation a step further and cells differentiate into a cell type of another lineage) and reprogramming (which aims to induce differentiated cells into a pluripotent state) [26]. Regenerative therapies consist of different technological approaches, such as soluble molecules, gene targeting, stem cell treatment, tissue engineering and cell reprogramming [41]. In this review we are only discussing the existing cell-based and growth factor-based in vitro and in vivo studies and therapies that are at preclinical and clinical level. For readers interested on the remaining regenerative 
therapies, which are not included in this review, we would like to refer to previous review papers [40, 42-45].

\section{Growth factor-based therapies}

Growth factors are signaling proteins (tissue hormones) that influence the metabolism of other cells [46]. Growth factors are released at the wound site and are required for communication between a variety of cells like fibroblasts, myofibroblast, smooth muscle cells, endothelial cells, keratinocytes and immune cells. The exogenous application of growth factors has been proven to affect the wound healing process $[47,48]$. Different studies in human patients have confirmed that growth factors such as platelet-derived growth factor (PDGF) play a role in enhancing the wound healing rate in acute wounds and even provide complete healing in chronic wounds [49-51].

The main growth factors currently known to be involved in the wound healing process include PDGF, epidermal growth factor (EGF), fibroblast growth factor (FGF), insulin-like growth factor $\left(\mathrm{IGF}_{1}, \mathrm{IGF}_{2}\right.$ ), vascular endothelial growth factor (VEGF), TGF- $\beta$ [52-55] and keratinocyte growth factor (KGF) [53]. To date only PDGF has been approved by the US Food and Drug Administration (FDA) and the European authorities (EMEA) for clinical application in patients $[56,57]$. An overview of the most cited growth factor-based therapies for skin wound management in animals models are summarized in Table 1.

Table 1. Overview of most cited growth factor-based therapies for skin wound management in animals and their functional effects

\begin{tabular}{|c|c|c|c|c|}
\hline Reference & Therapy & In vivo model & $\begin{array}{l}\text { Type of } \\
\text { wound }\end{array}$ & Functional in vivo effects \\
\hline $\begin{array}{l}\text { Carter et al., 2003; DeRossi et } \\
\text { al., 2009 }\end{array}$ & Autologous PRP-gel & Horse & Full thickness & Rapid epithelialization and collagen organization \\
\hline Monteiro et al., 2009 & Autologous PRP & Horse & Full thickness & No quality improvement or healing enhancement \\
\hline lacopettietal., 2011 & Autologous PRP-gel & Horse & Torn wound & No exuberant granulation and minimum scarring \\
\hline Kim et al., 2009 & Autologous PRP gel & Dog & Chronic & Reduced swelling and hair regrowth at wound margin \\
\hline Man et al., 2001 & Autologous PRP-gel & Human & Surgical flap & Improved healing with short recovery time \\
\hline Galiano et al., 2007 & Autologous VEGF & Diabetic mice & Full thickness & Enhanced re-epithelialization, matrix deposition and cellular proliferation \\
\hline Tsuboi and Rifkin, 1990 & RechFGF-2 & Diabetic mice & Full thickness & $\begin{array}{l}\text { Improved re-epithelialzation, increase of macrophages, fibroblasts, } \\
\text { neovascularization and granulation tissue. }\end{array}$ \\
\hline Shi et al., 2013 & Rec hbFGF & Rabbit/rat & Full thickness & $\begin{array}{c}\text { Stimulate fibroblast growth, reduce scar formation and regulate } \\
\text { inflammatory response }\end{array}$ \\
\hline Brown et al., 1993, 1994 & $\begin{array}{l}\text { Rec hPDGF and Rec hTGF- } \\
\text { alpha }\end{array}$ & $\begin{array}{l}\text { Normal and diabetic } \\
\text { mice }\end{array}$ & Full thickness & Enhanced collagen deposition, granulation tissue formation and maturation. \\
\hline Kim et al., 2010 & Rec hEGF & Mice & Full thickness & $\begin{array}{l}\text { Reduced scaring, suppressing inflammation, decreasing TGF- } \beta_{1} \text { and } \\
\text { mediating collagen formation }\end{array}$ \\
\hline Yu et al., 2007 & Rec hIGF & Diabetic mice & Full thickness & $\begin{array}{l}\text { Increased hypoxia-inducible factor } 1-\alpha \text { protein synthesis and function in } \\
\text { diabetic wounds }\end{array}$ \\
\hline Tsuboi et al., 1995 & $\begin{array}{l}\text { hIGF-I and IGF-1 binding } \\
\text { protein }\end{array}$ & $\begin{array}{l}\text { Diabetic mice } \\
\text { Normal rabbit }\end{array}$ & Full thickness & Increased granulation tissue formation and capillary number \\
\hline Yoshida et al. 2003 & Rabbit HGF & Mice & Full thickness & $\begin{array}{l}\text { Enhanced re-epithelialization, neovascularization and granulation tissue } \\
\text { formation }\end{array}$ \\
\hline Li et al., 2013 & hHGF & Diabetic rat & Full thickness & $\begin{array}{l}\text { Enhanced re-epithelialization, neovascularization and granulation tissue } \\
\text { formation }\end{array}$ \\
\hline
\end{tabular}

Basic fibroblast growth factor (bFGF); epidermal growth factor (EGF); hepatocyte growth factor (HGF), Human (h); Recombinant (Rec);insulin-like growth factor (IGF); platelet Basic fibroblast growth factor (bFGF); epidermal growth factor (EGF); hepatocyte growth factor (HGF), Human (h); Recombinant (Rec);ins
derived growth factor (PDGF); platelet rich plasma (PRP); transforming growth factor-beta (TGF- $\beta$ ); vascular endothelial growth factor (VEGF).

Platelet-Rich plasma. Autologous platelet-rich plasma (PRP) is blood plasma that has been enriched with platelets through specific centrifugation. The platelet count is often two to four times higher than normal [46]. Platelets are cytoplasmic fragments derived from bone marrow megakaryocytes and contain several types of growth factors and cytokines that might stimulate wound healing [58]. They activate the inflammatory process by releasing cytokines (such as interleukin (IL)-1 $\alpha,-1 \beta$ and -6 and tumor necrosis factor-alpha (TNF- $\alpha$ )), enhance collagen production (FGF-2, IGF-1, TGF- $\beta$ ), stimulate fibroblast to myofibroblast transformation (TGF- $\beta$ ), initiate angiogenesis (EGF-2. VEGF-A, TGF- $\beta$ ) and promote reepithelialization (EGF, FGF-2, IGF-1, TGF- $\alpha$ ) $[48,59,60]$. The main difficulty in assessing the therapeutic effects of PRP is to define which growth factor(s) were at the origin of the observed effects since PRP delivers a mixture of growth factors associated with natural scar healing [46].

There are a number of in vivo studies in dogs and horses regarding the use of PRP for cutaneous wound therapy. Carter et al. [61] and DeRossi et al. [62] reported that during 
equine wound healing PRP gel promoted epithelial differentiation and regeneration. In the same species, a case study reported by Iacopetti et al. [63] indicated that topical treatment with autologous PRP enhanced healing of large skin wounds. In contrast to the above findings, evaluation of the effect of PRP on wounds of the distal aspect of forelimb in horses indicated excessive granulation tissue development and a significantly slower wound healing [64]. Recently, Broeckx et al. [65] also reported on the inferior regenerative effect of PRP treatment in comparison to skin-derived SCs for the treatment of full thickness skin wounds in horses. On the other hand, Kim et al. [66] studied the curative effect of autologous PRP on a large skin lesion in a dog and reported a positive outcome.

In humans, PRP has been applied as a medical device for a number of diseases and injuries, such as cutaneous wounds. PRP received special attention because of its use in treating sport injuries in professional athletes [67]. A study by Man et al. [68] demonstrated quantitative improvements of human skin wound healing after topically treating cutaneous flaps with autologous PRP. Other studies on human patients with chronic wounds of various etiologies treated with PRP gel also showed some degree of improvement, reflected by reduction of wound area, volume and wound closure $[69,70]$.

Platelet-derived growth factor. PDGF is one of the initial factors secreted after injury and promotes cellular reactions throughout all phases of the wound healing process. PDGF exists in three isoforms: PDGF-AA, -BB, and -AB [71]. It is mainly secreted from the $\alpha$-granules of the platelet [72], but is also produced by different cells present in early wound healing, i.e. macrophages, keratinocytes, fibroblasts and endothelial cells $[48,72]$. The level of PDGF and its receptor have been demonstrated to be low in diabetic and aged mice which display a delayed injury response [48]. In agreement with the latter study, PDGF levels are depressed in non-healing human ulcers [73], probably due to lower production and/or higher protease mediated degradation. Therefore, wound treatment using exogenous PDGF has been studied and was found to be beneficial for patients with chronic wounds [74, 75]. As a result of FDA approval, PDGF-BB has been extensively used for treating diabetic ulcers [75, 76]. Despite this approval, there have been reports showing a limited clinical success. This might be due to underexpression of PDGF receptor by residing cells [55], or by proteolytic enzymes causing a fast degradation of the GF [77]. Moreover, a single factor may not be sufficient as a therapeutic tool because of the complexity and perseverance of a chronic wound. Therefore, sustained GF delivery systems with a combined and/or case specific approach might be necessary to enable optimal wound healing and closure $[76,78,79]$. Recently, a combination of AMD3100 (which mobilizes marrow-derived progenitor cell) and PDGF-BB therapy has synergistically shown to improve progenitor mobilization and trafficking, resulting in significantly improved diabetic wound closure and neovascularization [80].

Fibroblast growth factor. FGF-1, $-2,-7,-10$ and -22 are all being expressed upon dermal injury [81]. FGF-1 refers to acidic and FGF-2 to basic FGF and are produced by inflammatory cells, vascular endothelial cells, fibroblasts and keratinocytes and contribute to re-epithelialization, angiogenesis and granulation tissue formation $[48,82]$. In addition to their direct role in wound healing, FGF-7 and -10 also stimulate the production of TGF- $\alpha$ by dermal keratinocytes, indirectly supporting epithelialization [83].

Studies in animal models showed that there is abnormal expression of FGF-1, -2 and -7 in wounds of diabetic aged animals [84]. Administration of FGFs successfully improved wound healing in these animals [85]. In this regard, Tsuboi and Rifkin [86] reported that bFGF (FGF-2) accelerated wound healing in a diabetic mouse model. Another study by Shi et al. [87] reported that bFGF regulated ECM synthesis and degradation through regulating collagen distribution and $\alpha$-smooth muscle actin ( $\alpha$-SMA) and TGF- $\beta 1$ expression. Moreover, bFGF application resulted in reduced scarring and promoted wound healing by inhibiting the TGF- $\beta 1 /$ SMAD-dependent pathway. Therefore, it has been suggested that bFGF positively influences hypertrophic scar formation in vitro and in vivo [87]. Based on the aforementioned promising animal models, clinical trials in humans were performed where FGF-1 and -2 were used for treating chronic (burn) wounds and resulted in a modest improvement in the healing rates in some studies [81, 88]. In another study by Ma et al. [89], the use of human 
recombinant FGF-1 resulted in accelerated healing of deep partial-thickness burn wounds. Future studies may provide better insights on the beneficial effects of different types of FGFs in different patient groups.

Transforming growth factor- $\beta$. The TGF- $\beta$ family consists of TGF- $\beta 1-3$, bone morphogenic proteins (BMP) and activins. In mammals mainly TGF- $\beta 1,-\beta 2$ and $-\beta 3$ isoforms are found, but TGF- $\beta 1$ predominates in cutaneous wound healing. They are produced by macrophages, fibroblasts, keratinocytes and platelets [81]. TGF- $\beta$ is a multifunctional growth factor that attracts new fibroblasts and macrophages to the wound site, stimulates fibroblast proliferation and collagen synthesis, reduces extracellular matrix degradation [90] and modulates the immune system [91].

TGF- $\beta 1,-\beta 2$, and $-\beta 3$ have overlapping but diverse functions during wound healing. Both TGF- $\beta 1$ and $-\beta 2$ have been shown to induce fibroblast-myofibroblast differentiation, ECM deposition, contraction, and scar formation, whereas TGF- $\beta 3$ has the ability to reduce scarring [81]. Much of the current knowledge on TGF- $\beta$ action in wound healing has been obtained from animal studies using incisional and/or excisional wound models [91]. Preclinical studies indicated a significant reduction in scarring and considerably improved dermal architecture after intradermal injection of avotermin (TGF- $\beta 3$ ) in adult rats [92, 93]. Moreover, phase II clinical trials showed that intradermal injections of avotermin in scar revision surgery [94] and bilateral leg wounds [95] were well tolerated and resulted in significantly improved scar appearance compared to placebo. In addition, other phase II clinical trials demonstrated significant improvement in scar formation with avotermin treatment as well [96].

Vascular endothelial growth factor. During wound healing, VEGF is secreted by platelets, macrophages, fibroblasts, and keratinocytes and has a paracrine effect on endothelial cells, inducing and/or supporting wound angiogenesis [48]. It has been demonstrated that topical VEGF application accelerates diabetic wound repair in a mouse model through increased epithelialization, angiogenesis, granulation tissue deposition and minimum scar formation [97]. In another murine study, inhibiting angiogenesis through endostatin caused a delay in wound healing, which almost completely reversed after application of topical VEGF [98], confirming the strong angiogenic capacity of this growth factor. However, recombinant VEGF necessitates regular topical applications for sustained drug level in the skin tissue, which may have been the reason for unsuccessful clinical trials in diabetic foot ulcers [99]. Recently, Tan et al. [100], have used collagen scaffolds with VEGF in a diabetic rat wound model and found that the treatment resulted in an enhanced healing rate, improved vascularization and increased level of VEGF in the granulation tissue. A phase I trial on safety of topical recombinant human VEGF (telberim) in patients with chronic diabetic foot ulcers by Hanft et al. [101] showed that the treatment was well tolerated and reduced time to complete ulcer healing.

Epidermal growth factor. EGF is secreted by platelets, macrophages, fibroblasts, and bone marrow-derived mesenchymal stem cells [81]. This growth factor plays an important role in tissue homeostasis by influencing epithelial cell proliferation, growth, and migration. It also provides nutritional support by promoting angiogenesis, and is therefore considered as a key player in wound healing and tissue generation [102]. It has been reported that treatment of cultured epithelial cells with EGF, stimulated outwards migration of keratinocyte colonies [103]. It has also been demonstrated that EGF stimulates keratinocyte division and epidermal regeneration in vitro and in vivo, respectively [104].

Experimental studies in animals have shown that the topically applied EGF accelerates epidermal regeneration of partial-thickness wounds and second-degree burns [105]. Much later, Kim et al. [106] studied the role of EGF in the formation of cutaneous scars in mice using full thickness wounds, and concluded that local application of the EGF enhanced wound healing rate and reduced cutaneous scaring. These authors suggested that the latter effects were mediated by suppressing the inflammatory response, decreasing TGF- $\beta 1$ expression and mediating collagen production. Recently, Lee et al. [107] treated laser induced murine burn wounds with EGF and reported a significantly enhanced wound healing effect in 
the EGF treated group. Clinical studies in humans have also demonstrated an accelerated epidermal regeneration of partial-thickness wounds and second-degree burns after topical EGF treatment [105]. In another study by Brown et al. [108], human chronic wounds which were unresponsive to conservative treatments showed accelerated healing after topical application of EGF in 8 out of 9 patients. EGF has not only been widely used for the treatment of wounds but also for cancer therapy and vaccines, based on its cell proliferation regulatory properties [109].

Insulin-like growth factor. Inactive forms of both IGF-I and -II can be found in plasma at high concentration and are produced by most tissues/cells, such as liver, kidneys and fibroblasts [71]. In vitro assays assessing re-epithelialization showed that both EGF and IGF promote migration of keratinocytes [110]. The same study demonstrated that EGF and IGF have synergistic effects. Furthermore, it has been reported that levels of IGF-1 are lower in non-healing wounds of patients suffering from diabetes [111]. Accordingly there are many studies indicating that the addition of exogenous IGF-1 accelerates wound healing in diabetic mice [111-113], non-diabetic mice [113] and rabbits [112]. In addition, an in vivo study by Greenhalgh et al. [114] showed enhanced tissue repair in genetically diabetic mice when treated with PDGF and IGF-II, again with a synergistic effect. The aforementioned studies implicate that IGF has the strongest effect when being used in combination with other growth factors.

Hepatocyte growth factor. HGF is secreted by mesenchymal cells and is well known to regulate cell growth, motility, and morphogenesis in several cell types, including epithelial and endothelial cells, confirming its contribution to epithelial repair and neovascularization $[115,116]$. However, there are only few reports on in vivo studies of HGF in animal models. In this regard, an in vivo study by Yoshida et al. [117] showed that when normal rabbit immunoglobulin G (IgG) or neutralizing anti HGF IgG was continuously applied to full thickness excisional wounds of mice, the amount of capillary vessels and granulation expansion declined with the neutralization of HGF. Likewise, neutralization of endogenous HGF on days 4 and 7 post-wounding resulted in retardation of re-epithelization and wound closure. Li et al. [118] confirmed these findings in Wistar rats. Based on the aforementioned studies it can be concluded that HGF is a key factor in skin wound healing by promoting neovascularization, granulation tissue formation and re-epithelialization.

What are the possible risks/side-effects of the above mentioned growth factors? It has been demonstrated that recombinant growth factors for the treatment of chronic wounds undergo rapid enzymatic degradation. The growth factors which are exogenously applied into the wound site have low bioactivity and availability because they are quite large and penetrate rather slow in the surrounding tissue. Repeated administration of high nonphysiologically concentrations are necessary to support the healing, however, the excess concentration of growth factors results in local toxicity, adverse effects [119-121] and may lead to increased risk of cancer [122]. Nevertheless, this problem might be solved by the construction of polymer-based/biomaterial growth factor delivery systems which regulate the release of growth factors [123].

\section{Cell-based therapies}

Cell-based therapies are defined as the introduction of new cells into a tissue in order to treat diseases or regenerate damaged tissue. Wound healing is a complex process which requires the coordinated action of multiple cell types $[124,125]$ which is a reaction to a variety of cytokines and micro-environmental conditions [23, 125]. Cell-based therapies might be considered as an alternative approach to growth factors for wound management. Cells so far studied for cutaneous wound healing effect include stem cells, keratinocytes, fibroblasts and platelets. The latter ones have been discussed under the previous section because of the growth factor secretion. An overview of the most frequently reported cellbased therapies for skin wound management in animals models is presented in Table 2.

Cell-based therapies can, from a regulatory viewpoint, be classified either as human tissues and cells (Directive 2004/23/EC) or as advanced therapy medicinal products (ATMP, 
Directive 2001/83/EC and Regulation 1394/2007). The FDA has implemented a regulatory outline that controls cell-based products based on three topics: (i) prevention of using contaminated cells, (ii) prevention of handling that may cause contamination and (iii) clinical safety of cells used [126]. There is a substantial gap between optimistic laboratory-based research and approved stem cell based products (SCBPs) in this fast emerging field [127]. In order to translate SCBPs from bench to bedside and ensure patient safety, compliance with existing regulations and guidelines is required to ensure that the product is safe, pure and potent. Meeting good tissue practices (GTP), good manufacturing practices (GMP) and good clinical practices (GCP) requirements is also indispensable [126].

Stem cells. Stem cells are defined as unspecialized cells that have two defined properties: the ability to differentiate into other cells and the ability to self-regenerate [128]. Stem cells may be categorized according to their potency: totipotent, pluripotent, multipotent or progenitor cells [129] or conferring to the sources they originate from: embryonic stem cells (ESCs), fetal stem cells, neonatal or umbilical cord stem cells and adult stem cells [130]. Since adult, post-natal stem cells escape the ethical and safety issues associated with ESCs, adult stem cells are an important aspect for cell-based therapies [131] and hence reviewed in this article.

Table 2. Overview of most cited cell-based therapies for skin wound management in animals and their functional effects

\begin{tabular}{|c|c|c|c|c|c|}
\hline Reference & Therapy & $\begin{array}{c}\text { Route of } \\
\text { administration }\end{array}$ & In vivo model & $\begin{array}{l}\text { Type of } \\
\text { wound }\end{array}$ & Functional in vivo effects \\
\hline Stoff et al., 2009 & hMSCs & Topical & Rabbit & Incisional & Increased tensile strength, granulation tissue and reduced scar formation \\
\hline $\begin{array}{l}\text { Nakagawa et al., } \\
2005\end{array}$ & hMSCs and Rec bFGF & Topical & Rat & $\begin{array}{c}\text { Full- } \\
\text { thickness }\end{array}$ & Transdifferentiation into skin cells \\
\hline $\begin{array}{l}\text { Shumakov et al., } \\
2003\end{array}$ & Allogenic BM-MSCs & Topical & Rat & Deep burn & $\begin{array}{c}\text { Decreasing infiltration of inflammatory cells, increased neovascularization } \\
\text { and granulation tissue }\end{array}$ \\
\hline $\begin{array}{l}\text { Sasaki et al., } \\
2008\end{array}$ & Allogenic BM-MSCs & IV (tail vein) & Mice & $\begin{array}{c}\text { Full } \\
\text { thickness }\end{array}$ & MSCs transdifferentiated into keratinocytes, endothelial cells and pericytes \\
\hline Lee et al., 2011 & hESC-EPC & $\begin{array}{l}\text { Topical and } \\
\text { subcutaneous }\end{array}$ & Rat & $\begin{array}{l}\text { Full } \\
\text { thickness }\end{array}$ & $\begin{array}{l}\text { Increased tensile strength, rapid formation of granulation tissue and re- } \\
\text { epithelialization }\end{array}$ \\
\hline $\begin{array}{l}\text { Pratheesh et al., } \\
2014\end{array}$ & $\begin{array}{l}\text { CaprineWarton's jelly- } \\
\text { derived MSCs }\end{array}$ & $\begin{array}{l}\text { Subcutaneous } \\
\text { (4 edges) }\end{array}$ & Rabbit & $\begin{array}{l}\text { Full } \\
\text { thickness }\end{array}$ & $\begin{array}{c}\text { Increasing wound contraction, epithelialization, vascularization and } \\
\text { collagenization }\end{array}$ \\
\hline $\begin{array}{l}\text { Spaas et al., } \\
2013\end{array}$ & Autologous PBSCs & Intradermal and IV & Horses & Chronic & More rapid wound closure and crust formation \\
\hline
\end{tabular}

Bone marrow (BM); basic fibroblast growth factor (bFGF); human embryonic stem cell (hESC); endothelial precursor cells (EPCs); intravenous (IV); mesenchymal stem cells (MSCs); peripheral blood stem cells (PBSCs).

To date, the role of stem cells in wound healing is progressively being valued. For this reason, an increasing number of regenerative therapies for wound healing are being developed and encouraged by promising findings from both animal and human studies. It has been suggested that stem cell application has more advantages than the use of single biological factors for several reasons [132]. Indeed, stem cells have the capacity to differentiate into multiple cell lineages, influence environmental elements and produce healing enhancing factors indicating a great potential as a therapeutic tool $[132,133]$.

Mesenchymal stem cells. Adult mesenchymal stem cells (MSCs) are multipotent cells found in mesodermal tissues [134, 135]. These cells represent a unique tool for tissue engineering. Indeed, it has been reported that MSCs can differentiate into multiple lineages such as osteoblasts, chondroblasts, adipocytes, tenocytes and myocytes [136]. Rather than their differentiation potential, the secretory/paracrine effects of MSCs have been found to increasingly attribute to the therapeutic efficacy of MSC transplantations. In this regard, it has been demonstrated that MSCs have important potential immunomodulatory effects. Indeed, MSCs can directly attenuate inflammatory responses by decreasing the secretion of the pro-inflammatory cytokines such as TNF- $\alpha$ and interferon- $\gamma$ (IFN- $\gamma$ ) $[137,138]$ while enhancing the production of anti-inflammatory cytokines including IL-10 and IL-4 in parallel [137]. Therefore, the anti-inflammatory properties of MSCs increase their importance for chronic wound treatment. Particularly vasculogenesis and angiogenesis, which are crucial steps in wound healing are also stimulated by paracrine factors released by MSCs, including IGF-1, PDGF-BB [39], VEGF, angiopoietin-1 [39, 139], bFGF and KARGER 
matrix metalloproteinase-2 [138]. In addition, MSCs are recognized to have antibacterial activities [140], either by secretion of antimicrobial factors or indirectly by secretion of immunomodulative factors which up-regulate phagocytosis and bacterial killing $[140,141]$.

A number of parameters can assess experimental and clinical wound healing upon MSC therapy. For clinical wound assessment, parameters like histology, tensiometry and tracing of the transplanted cells in the wound tissue over time are currently used. Histology evaluates the status of infiltration of inflammatory cells, vascular proliferation, fibroplasia, presence and depth of scar tissue, epithelialization rate and absence of adnexa including hair follicles, apocrine glands and smooth muscle. The parameters used to assess wound healing, include measuring wound size/contraction, analysis of wound scores of granulation tissue formation, vascularity, dermal thickness and skin resurfacing.

Recent reports consider that both allogenic and autologous MSCs may positively impact all phases of wound repair in humans as well as animals [23]. Shumakov et al. [142] reported that MSC treatment of deep burn wounds in rats resulted in lower inflammatory cell infiltration and faster vessel and granulation tissue formation. It was also suggested that the cells produce bioactive substances that would enhance the regeneration process. Moreover, Nakagawa et al. [143] reported that MSCs together with bFGF accelerate acute wound healing and showed that the human MSCs transdifferentiate into epithelium in a rat skin defect model. Furthermore, a study by McFarlin et al. [144] showed that systemic or local administration of bone marrow-derived MSCs augments healing of surgical fascial or cutaneous wounds by increasing collagen production (I and III) and hence increasing wound bursting and tensile strength in rats. The latter study reported that MSCs may also facilitate wound healing by trans-differentiating into myoblasts and keratinocytes after migration to the wound site. Transplantation of human MSCs also resulted in promotion of incisional wound repair in rabbits and resulted in increased tensile strength, granulation tissue formation and decreased evidence of scar formation [145]. Experiments by Wu et al. [139], Sasaki et al. [146] and Tamai et al. [147] demonstrated that bone marrow-derived MSCs enhance wound healing by undergoing epidermal trans-differentiation and angiogenesis. Recently, Kim et al [138] applied allogenic MSCs on skin wounds in a canine experimental wound model and demonstrated that MSC treatment caused accelerated wound closure and enhanced collagen production, cellular proliferation and angiogenesis. Apart from bone marrow, transplanted MSCs isolated from Wharton's jelly of caprine umbilical cord to full-thickness skin incision of goats Azari et al. [148] and full thickness excisional skin wounds in rabbit [149] resulted in less inflammation, thinner granulation tissue formation with minimum scar in the incisional wound and significantly higher percentage of wound contraction, epithelialization and collagenization with matured vascularization in the excisional wounds. In addition, peripheral blood-derived stem cells (PBSCs) have been reported to enhance different wound healing parameters of chronic naturally occurring wounds in horses, such as granulation tissue and scar tissue formation [150]. However, the latter study contained no control groups with untreated wounds, so further research is definitely warranted.

In the study by Vojtassák et al. [151], bone marrow aspirate of a diabetic patient was applied directly to the foot wound, injected into the margins and finally covered with a prepared autobiograft. The wound was treated again on day 7 and 17 with cultured MSC and this resulted in wound size decrease and increase in dermal vascularization and thickness. Falanga et al [152] suggested that bone marrow-derived MSCs accelerated skin resurfacing of defects from surgically excised non-melanoma skin cancers when combined with topically applied fibrin spray. Dash et al [153] indicated that simultaneous intramuscular and topical administration of autologous bone marrow-derived MSCs for the treatment of non-healing ulcers of low extremities, enhanced the healing process and clinical parameters. A similar result was also observed when Jain et al. [154] used a single application (injection and topically application) of autologous bone marrow-derived cells for the treatment of chronic lower extremity wounds. The study conducted by Lu et al [155], also demonstrated the clinical benefits of intramuscular administration of bone marrow-derived MSCs for treatment of diabetic critical limb ischemia and foot ulcers. 
Hematopoietic stem cells. Besides MSCs, the bone marrow also contains hematopoietic stem cells (HSCs). The HSCs are a well-characterized population of self-renewing cells [156], which are currently mainly being used for treating acquired and inherited bone marrow and hematologic disorders in man [131]. Krause et al. [157] conducted studies on multi-organ, multi-lineage engraftment using a single bone marrow-derived HSC which gave rise to follicular epithelial cells, sebaceous gland cells, epidermal keratinocytes and even dendritic cells after their transplantation in mice. They suggested that HSCs could possibly contribute to the clinical treatment of skin wounds. In this regard, it has also been reported that topical application of full thickness excisional wounds in diabetic mice with a side population of HSCs resulted in a high percentage of wound closure [158]. Nevertheless, more research is warranted in order to determine whether HSCs alone have similar wound healing enhancing effects as other adult stem cell types reported so far.

Epithelial stem cells. Epithelial stem cells (EpSCs) are adult stem cells which are quiescent yet have the capacity to self-renew and differentiate into at least one cell type [159]. A clear distinction should be made between dermal papillae stem cells that contribute to multiple skin appendage formation and epidermal stem cells which are mainly designed to reconstitute epidermis. There are different types of EpSCs which have been identified in the hair follicle [159] or the basal layer of the epidermis [65]. In haired skin, progeny of bulge stem cells migrate towards new epidermis for re-epithelialization [37]. Yang et al. [160] cultivated epidermal adult stem cells (EpiASCs) on bioengineered dermis to recreate artificial skin which was effectively transplanted in goats with acute full thickness skin defects. Their results showed that EpiASCs were able to rebuild the skin with hair formation. Recently, Broeckx et al. [65] reported the isolation and purification of equine epidermisderived EpSCs. The authors noticed that EpSC addition to PRP treatment considerably enhanced several wound healing parameters. Indeed, the dermis was thinner and displayed less granulation tissue than the control wounds, which was a desired feature in equine skin, since horses tend to form hypergranulation tissue. Moreover, the latter study reported a considerable increase in vascularization, elastin content and follicle-like structures in the EpSC-treated group. Since these cells are lineage committed and preliminary experiments demonstrated similar healing enhancing capacities as MSCs, EpSCs might be considered as a valuable alternative.

Adipose-derived stem cells. Adipose-derived stem cells (ASCs) represent alternative sources of multipotent cells with characteristics similar to bone marrow-derived MSCs [161, 162]. Compared to BM-MSCs, ASCs are more abundant which makes them easier to isolate, and hence they are considered as an attractive source for wound regeneration [163]. An in vitro study by Lee et al. [163] showed that ASC conditioned medium may have beneficial effects on wound healing by increasing proliferation of immortalized human keratinocytes (HaCaT cells) and fibroblasts. Moreover, the latter study reported an increased contraction of the collagen matrix where the fibroblasts reside, indicating the importance of paracrine effects on surrounding cells. Lee et al. [164] found that ASCs enhanced full thickness wound healing. Moreover, it has been demonstrated that ASCs possess anti-inflammatory, vasculogenic and angiogenic properties, which are lacking in other cell types, such as dermal fibroblasts. Due to these paracrine advantages, ASCs can be used as a substitute for fibroblasts in grafting engineered skin [165]. Nevertheless, more protracted studies are necessary to demonstrate the working mechanism of these cells.

Differentiated cells. Adult terminally differentiated cells are also used for skin wound treatment. To date, keratinocytes, fibroblasts and adipose-derived stromal vascular fraction (SVF) cells are being applied in a clinical setting of human skin wounds. They are mainly combined with artificial dermis to optimize wound healing [166]. Tissue engineered skin has been developed due to restrictions correlated with autografts. Culturing autologous cells takes time and may result in donor site pain and healing insufficiency for patients with large skin defects, scarring, infection and/or slow healing $[167,168]$. On the other hand, when allogenic sources of adult cells are used, immune rejection may occur and compromise the treatment outcome [168]. In recent years, skin tissue engineering has made significant

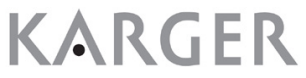


advances, however, several factors still delay its progress. Besides the critical choice of using the correct cell type, it remains a challenge to generate a detailed and complex new skin comprising all the necessary cells and to arrange them in a specific 3D pattern [169]. Since mature cells are mostly terminally differentiated, these cells are not the first choice for tissue engineering and regenerative medicine compared to stem cells [168]. For more information concerning several skin tissue engineering methods, the authors would like to refer to other review papers [170-172].

Skin keratinocytes consist of constantly renewing cells, and are being appreciated from a scientific and therapeutic point of view. Keratinocyte-based wound healing therapies exist in different forms. Chronic leg ulcers are being treated for a long time with autologous [173, 174] and allogenic epidermal keratinocytes [175]. Since, several keratinocyte sources have been used in humans: own skin cells, cells from cadavers and bioengineered "immortalized" keratinocytes. Researchers have also used keratinocytes as one component in cellular constructs and reported that they contributed to improved quality of wound healing $[176,177]$. A retrospective study by Auxenfans et al. [178] showed that cultured allogenic keratinocytes allowed fast healing of deep second degree burns in human patients. KazemiDarabadi et al. [179] described that allogenous skin fibroblast transplantation for diabetic wounds in sheep positively affected the wound healing by increasing re-epithelialization, number of fibroblasts and blood vessels.

Adult bone marrow derived cells have also been studied for experimental wounds in animals and human clinical cases. A study by Yamaguchi et al. [180] showed that these cells accelerate wound healing in rats by differentiating into wound myofibroblasts. An experimental burn wound model in rabbits [181], surgically created wounds in rabbits [182, 183] and clinical cases in dogs [184] demonstrated significantly more early vascularization, fibroplasia and early maturation of collagen using autologous bone marrow-derived mononuclear cells. Apart from acute wound cases, a study conducted by Lu et al [155] showed the clinical benefits of intramuscular injection of fresh bone marrow-derived mononuclear cells for treating diabetic critical limb ischemia and foot ulcers, yet with a slower healing rate in comparison with bone marrow-derived MSCs. Badiavas and Falanga [185] treated chronic non-healing wounds in humans by direct application of bone marrow derived cells and found that the treatment resulted in wound closure and tissue reconstitution.

\section{Hurdles in regenerative therapies for skin wound healing and future perspectives}

Due to recent advances in regenerative medicine in general, the specific understanding of skin wound healing mechanisms has considerably improved. Nevertheless, several key issues and questions remain when administering cells or growth factors to skin wounds, which need to be addressed in future studies on skin regenerative therapies.

Growth factors are indispensable for directing cell to cell and cell to matrix interactions during wound repair. However, growth factor therapies do not consider physiological interactions between growth factors to control the repair process. Therefore, using only one growth factor is possibly not the optimal way to go. In fact, during in vivo wound repair, protein growth factors often interact with non-protein soluble mediators (i.e. lipids). In fact, these lipids function synergistically with growth factors, stimulating their function and enhancing wound healing. For this reason, the combination of growth factors with other bioactive lipids might generate some interesting findings [76]. Moreover in some cases there is insufficient bioavailability of growth factors, because of reduced synthesis and/or enhanced degradation in chronic wounds [119]. Therapeutic approaches for skin wounds might on the one hand require repeated administration of exogenous growth factors, on the other hand, high dose administrations might result in adverse effects in chronic wounds [119]. Moreover, it has been suggested that due to the complexity and need of repeated delivery, a single entity may not suffice. Thus, the use of a combination therapy and/or a patient specific approach may well be necessary for optimal wound healing $[78,79]$. With recent advances,

\section{KARGER}


there have been attempts to address these aspects through the production of polymer-based (i.e biomaterial) controlled release growth factor delivery systems [123]. The main goal of such drug delivery systems would be to ensure the stability of the growth factor surrounded by proteases, extending its function at the injury site, minimizing systemic absorption, and inhibiting immune responses. In this regard, different types of systems have been reported such as proteinaceous ECM-derived, carbohydrate-based and synthetic vehicles. Several biodegradable or biocompatible delivery systems have been considered as safe by the FDA [76]. Still, a number of other challenges deserve more attention, including: i) increasing stability of encapsulated growth factors in the biomaterial/construct to allow release for longer periods, ii) difficulties in upscaling and iii) defining a suitable compartmentalization to allow multiple factor release with specific kinetics. The interactions among growth factors in cases of multiple delivery, their receptors and other ECM components are essential for delivery of regenerative therapies [186] and need further investigation.

Some issues that remain to be determined in cell-based therapies include age of the donor animal, optimal time of wound treatment, dose and route of administration of cells for skin wound therapy. In addition, the local micro-environment of the injured tissue should be taken into consideration. Both the in vivo study where MSCs from old mice inhibited (rather than promoted) wound healing of diabetic mice [187] and the in vitro decrease of epidermal stem cell activity of skin cultures from old men [188] strongly indicate that donor age is one of the concerns for stem cell therapy. In the case of enhanced fibrosis and scar tissue, the reduced blood supply, receptors and biological molecules might result in a failed therapy, because of the lack of an ideal environment for enhancing cell differentiation, proliferation and functioning $[189,190]$.

The use of allogenic multipotent MSCs without adverse reactions has been described in both humans and horses [191-197]. Moreover, MSCs can inhibit the innate immune reaction by inhibiting dendritic cell maturation and reducing macrophage and T-cell activity [198-202]. Furthermore, MSCs block both B-cell proliferation and IgA, IgG and IgM production [203]. Therefore, in future stem cell treated skin wound studies, the aforementioned parameters should be evaluated for different stem cell types. It has to be mentioned that many studies suggest that the main modus operandi of cell-based therapies is their paracrine effect. If this would be the case, it would implement that certain cell components or growth factors might be sufficient to achieve the required clinical improvements. Although the present literature study demonstrates similar functional in vivo effects after certain growth factor- and cellbased therapies, it does not allow us to conclude that stem cells only exert paracrine effects. Future studies might provide more answers to this complex, yet interesting matter.

Hereby we propose that the application of cell- and growth factor-based therapies in animals require a critical and cautious approach and all results should be carefully interpreted and reported [189].

\section{Conclusions}

Skin wound regenerative therapies are currently intensively studied. Several in vitro and in vivo studies have been conducted on regenerative strategies for wound healing in humans and different animal species. Regardless promising animal studies demonstrating accelerated wound healing, their clinical use still remains hampered because adequate delivery methods need further development. Therefore, clinical validation of the use of most of the cellular- and growth factor-based therapies is still in an early stage. Beneficial outcomes of fundamental research and preclinical trials require larger placebo-controlled field studies to confirm their efficacy. In addition, there is also a lack of information on longterm outcomes of skin wound treatment using such regenerative therapies. Nevertheless, for all the aforementioned reasons, researchers should be encouraged to increase the knowledge of growth factor- and cell-based regenerative therapies and future studies should focus on the development of a solid therapy for the treatment of skin wounds in mammals.

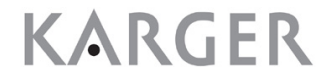




\section{Cellular Physiology Cell Physiol Biochem 2015;36:1-23 \begin{tabular}{l|l|l} 
DOI: 10.1159/000374049 & (C) 2015 S. Karger AG, Basel
\end{tabular} www.karger.com/cpb \\ Borena et al.: Regenerative Cutaneous Wound Therapies}

\section{Acknowledgments}

Bizunesh M Borena is supported by the Netherlands University Foundation for International Cooperation (NUFFIC).

\section{Disclosure Statement}

SYB and JHS declare competing financial interests and Pell Cell Medicals declares a patent with number W02014029778. The other authors declare no competing interests.

\section{References}

1 Theoret C: Tissue engineering in wound repair: The three "R"s-Repair, Replace, Regeneration. Vet Surg 2009;38:905-913.

2 Clark RA: Wound repair, overview and general considerations; in: Clark R (ed): The molecular and cellular biology of wound repair. Plenum Press, New York, 1996, pp 257-288.

- 3 Soo C, Beanes SR, Hu FY, Zhang X, Dang C, Chang G, Wang Y, Nishimura I, Freymiler E, Lonagker MT, Lorenz HP, Ting K: Ontogenic transition in fetal wound transforming growth factor-beta regulation correlates with collagen organization. Am J Pathol 2003;163:2459-2476.

-4 Gurtner GC, Werner S, Barrandon Y, Longaker MT: Wound repair and regeneration. Nature 2008;453:314321.

-5 Dudas M, Wysocki A, Gelpi B, Tuan TL: Memory coded throughout our bodies: molecular and cellular bases of tissue regeneration. Pediatr Res 2008;63:502-512.

-6 Kawasumi A, Saqawa N, Hayashi S, Yokoyama H, Tamura K: Wound healing in mammals and amphibians: toward limb regeneration in mammals. Curr Top Microbiol Immunol 2013;367:33-49.

-7 Singer AJ, Clark RA: Cutaneous wound healing. N Engl J Med 1999;341:738-746.

8 Kraft J, Lynde C: Giving burns the First, second and third degree: classification of burns". skincareguide.ca. Retrieved 2012-01-31.

-9 Edlich RF, Spengler MD, Rodeheaver GT: Mammalian bites. Compr Ther 1983;9:41-47.

10 Stashak TS, Theoret CL: Managing the acute injury; in: Orsini JA and TJ Divers, (eds): Manual of Equine Emergencies: Treatment and procedures Saunders. Philadelphia, 2007, pp. 189-236.

11 Wong VW, Sorkin M, Glotzbath JP, Longaker MT, Gurtner GC: Surgical approaches to creat murine models of human wound healing. J Biomed Biotechnol 2011;969618.

12 Sullivan TP, Eaglestein WH, Davis SC, Mertz P: The pig as a model of human wound healing. Wound Repair Regen 2001;9:66-76.

13 Wilmink JM, Nederbragt H, van Weeren PR, Stolk PW, Barneveld A: Differences in wound contraction between horses and ponies: the in vitro contraction capacity of fibroblast. Equine Vet J 2001;33:499-505.

14 Theoret CL, Wilmink JM: Aberrant wound healing in the horse: naturally occurring conditions reminiscent of those observed in man. Wound Repair Regen 2013;21:365-371.

15 Wilmink JM, van Weeren PR: Second-intention repair in the horse and pony and management of exuberant granulation tissue. Vet Clin N Am Equine Pract 2005;21:15-32.

-16 Nemes Z, Steinert PM: Bricks and mortar of the epidermal barrier. Exp Mol Med 1999;31:5-19.

17 Zhang A, Michniak-Kohn BB: Tissue engineering human skin equivalent. Pharmaceutics 2012;4:26-41.

18 Breitkeutz D, Mirancea N, Nischt R: Basement membranes in skin: unique matrix structures with diverse functions? Histochem Cell Biol 2009;132:1-10.

19 Iozzo RV: Basement membrane proteoglycans: from cellular to ceiling. Nat Rev Mol Cell Biol 2005;6:646656.

20 Breitkeutz D, Koxholt I, Thiemann K, Nischt R: Skin basement membrane: the foundation of epidermal integrity-BM function and diverse roles of bridging molecules nidogen and perlecan. Biomed Research International. 2013;2013;179784.

21 Maquart FX, Monboisse JC: Extracellular matrix and wound healing. Pathologie Biologie 2014;62:91-95. 


\section{Cellular Physiology Cell Physiol Biochem 2015;36:1-23 \begin{tabular}{l|l|l}
\hline DOI: 10.1159/000374049 & (C) 2015 S. Karger AG, Basel
\end{tabular}

22 Lazarus GS, Cooper DM, Knighton DR, Percoraro RE, Rodeheaver G, Robson MC: Definitions and guidelines for assessment of wounds and evaluation of healing. Wound Repair Regen 1994;2:165-170.

23 Maxson S, Lopez EA, Yoo D, Danilkovitch-Miagkova A, LeRoux M: Concise review: role of mesenchymal stem cells in wound repair. Stem Cells Trans Med 2012;1:142-149.

24 Ko SH, Nauta A, Wong V, Glotzbach J, Gurtner GC, Longaker MT: The role of stem cells in cutaneous wound healing: what do we really know? Plast Reconst Surg 2011;127:10s-20s.

25 Eming SA, Krieg T, Davidson JM: Inflammation in wound repair: molecular and cellular mechanisms. J Invest Dermatol 2007;127:514-525.

26 Jopling C, Boue S, Belmonte JCI: Dedifferentiation, transdifferentiation and reprogramming: three routes to regeneration. Nat Rev Mol Cell Biol 2011;12:79-89.

-27 Whitby DJ, longaker MT, Harrison MR, Adzick NS, Ferguson MW: Rapid epithelialization of fetal wounds is associated with early deposition of tenascin. J Cell Sci 1991;99:583-586.

-28 Wulff BC, Parent AE, Meleki MA, DiPietro LA, Schrementi ME, Wilgus TA: Mast cells contribute to scar formation during fetal wound healing. J Invest Dermatol 2012;132:458-465.

29 Cowin, AJ, Holmes TM, Brosnan P, Ferguson MWJ: Expression of TGF- $\beta$ and its receptors in murine fetal and adult dermal wounds. Eur J Dermatol 2001,11:424-431.

30 Martin P, Lewis J: Actin cables and epidermal movement in embryonic wound healing. Nature 1992;360:179-183.

-31 Nodder S, Martin P: Wound healing in embryos: a review. Anat Embryol 1997;195:215-228.

32 Dent JN: Limb regeneration in larvae and metamorphosing individuals of the South African Clawed toad. J Morphol 1962;110:61-77. Odelberg SJ: Unraveling the molecular basis for regenerative cellular plasticity. PLoS Biol 2004;2:e232. Blanpain C, Simons BD: Unravelling stem cell dynamics by lineage tracing. Nat Rev Mol Cell Biol 2013;14:489-502.

35 Morrison SJ, Spradling AC: Stem cells and niches: mechanisms that promote stem cell maintenance throughout life. Cell 2008;132:598-611. Blanpain C, Fuchs E: Plasticity of epithelial stem cells in tissue regeneration. Science 2014;344:1243. Ito M, Liu Y, Yang Z, Nguyen J, Liang F, Morris RJ, Cotsarelis G: Stem cells in the hair follicle bulge contribute to wound repair but not to homeostasis of the epidermis. Nat Med 2005;11:1351-1354.

38 Levy V, Lindon C, Zheng Y, Harfe BD, Morgan BA: Epidermal stem cells arise from the hair follicle after wounding. FASEB J 2007;21:1358-1366.

39 Chen L, Tredget EE, Wu PYG, Wu Y: Paracrine factors of mesenchymal stem cells recruit macrophages and endothelial lineage cells and enhance wound healing. PLoS One 2008;3:e1886.

-40 Dieckmann C, Renner R, Milkova L, Simon JC: Regenerative medicine in dermatology: biomaterials, tissue engineering, stem cells, gene transfer and beyond. Experimental Dematology 2010;19:697-706.

-41 Greenwood HL, Singer PA, Downey GP, Martin DK, Thorsteinsdottir H, Daar AS: Regenerative medicine and the developing world. PLoS Med 2006;3:e381.

42 Branski LK, Pereira CT, Herndon DN, Jeschke MG: Gene therapy in wound healing: present status and future directions. Gene Ther 2007;14:1-10.

43 Branski LK, Gauglitz GG, Herndon DN, Jeschke MG: A review of gene and stem cell therapy in cutaneous wound healing. Burns 2009;35:171-180.

44 Eming S, Krieg T, Davidson JM: Gene therapy and wound healing. Clin Dermatol 2007;25:79-92.

-45 Gauglitz GG, Jeschke MG: Combined gene and stem cell therapy for cutaneous wound healing. Mol Pharm 2011;8:1471-1479.

46 Fortier LA, Smith RK: Regenerative medicine for tendinous and ligamentous injuries of sport horse. Vet Clin North Am Equine pract 2008;24:191-201.

47 Steel DL, DUS Group: Clinical evaluation of recombinant human platelet derived growth factors for the treatment of lower extremity diabetic ulcers. J Vasc Surg 1995;21:71-81.

48 Warner S, Grose R: Regulation of wound healing by growth factors and cytokines. Physiol Rev 2003;83:835870.

49 Robson MC, Phillips LG, Thomason A, Robson L, Pierce G: Platelet derived growth factor-BB for the treatment of chronic pressure ulcers. Lancet 1992;339:23-25. 


\section{Cellular Physiology Cell Physiol Biochem 2015;36:1-23

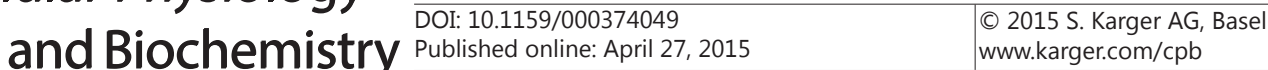 \\ Borena et al.: Regenerative Cutaneous Wound Therapies}

50 Robson MC, Phillips LG, Thomason A, Altrock BW, Pence PC, Heggers JP, Johnston AF, McHugh TP, Anthony MS, Robson LE, Odom LL, Yanagihara D, Pierce GF: Recombinant human platelet-derived growth factor-BB for the treatment of pressure ulcers. Ann Plast Surg 1992;129:193-201.

51 Mandracchia VJ, Sanders SM, Frerichs JA: The use of becaplermin (rhPDGF-BB) gel for chronic nonhealing ulcers: a retrospective analysis. Clin Podiatr Med Surg 2001;18:189-209.

-52 Koveker GB: Growth factors in clinical practice. Int J Clin Pract 2000;54:590-593.

-53 Grazul-Bilska AT, Johnson ML, Bilsk JJ, Redmer DA, Reynolds LP, Abdulah KM: Wound healing: the role of growth factors. Drugs Today (Barc) 2003;39:787-800.

-54 Jeffcoate W, Price P, Harding KG: Wound healing and treatments for people with diabetic foot ulcers. Diabetes Metab Res Rev 2004;20:S78-S89.

-55 Falanga V: Wound healing and its impairment in the diabetic foot. Lancet. 2005;366:1736-1743.

56 Papanas N, Maltezos E: Growth factors in the treatment of diabetic foot ulcers: new technologies, any promises? Int J Low Extrem Wounds 2007;6:37-53.

57 Murphy PS, Evans GR: Advances in wound healing: a review of current wound healing products. Plast Surg Int 2012;2012:190436.

58 Sandoval JA, Lopez C, Carmona JU: Therapies intended for joint regeneration in the horses. Arch Med Vet 2013;45:229-236.

59 Bennett NT, Schultz GS: Growth factors and wound healing: Part II. Role in normal and chronic wound healing. Am J Surg 1993;166:74-81.

-60 Li J, Chen J, Kirsner R: Pathophysiology of acute wound healing. Clin Dermatol 2007;25:9-18.

61 Carter AC, Jolly DG, Worden CE, Hendren DG, Kane CJM: Platelet-rich plasma gel promotes differentiation and regeneration during equine wound healing. Exp Mol Pathol 2003;74:244-255.

62 DeRossi R, Anciliero AC, Sliveira G, Oliveria F, Brito CR, Goncalves G, Bonucielli K: Effects of platelet-rich plasma gel on skin healing in surgical wound in horses. Acta Cir Bras 2009;24:276-281.

-63 Iacopetti I, Perazzi A, Ferrari V, Busetto R: Application of platelet rich gel to enhance wound healing in horses: a case report. J Equine Vet Sci 2012;32:123-128.

64 Monteiro SO, Lepage OM, Theoret CL: Effect of platelet-rich plasma on the repair of wounds on the distal aspect of the forelimb in horses. Am J Vet Res 2009;70:277-282.

65 Broeckx SY, Maes S, Martinello T, Aerts D, Chiers K, Marien T, Patruno M, Franco- Obregon A, Spaas JH: Equine Epidermis: a source of Epithelial-like Stem/Progenitor cells with in vitro and in vivo regenerative capacities. Stem Cells Dev. 2014;23:1134-1148.

-66 Kim JH, Park C, Park HM: Curative effect of autologous platelet-rich plasma on a large cutaneous lesion in a dog. Vet Dermatol 2009;20:123-126.

67 Hall MP, Band PA, Meislin RJ, Jazrawi LM, Cardone DA: Platelet-rich Plasma: current Concepts and application in sports medicine. J Am Acad Orthop Surg 2009;17:602-608.

-68 Man D, Plosker H, Winland-Brown JE: The use of autologous platelet rich plasma (platelet gel) and platelet poor plasma (fibrin glue) in cosmetic surgery. Plast Reconstr Surg 2001;107:229-237.

69 Mazzucco L, Medici D, Serra M, Panizza R, Rivara G, Orecchia S, Libener R, Cattana E Levis A, Betta PG, Borzini P: The use of autologous platelet gel to treat difficult-to-heal wounds: a pilot study. Transfusion 2004;44:1013-1018.

-70 Frykberg RG, Driver VR, Carman D, Lucero B, Borris-Hale C, Fylling CP, Rappl LM, Clausen PA: Chronic wounds treated with a physiologically relevant concentration of platelet-rich plasma gel: a prospective case series. Ostomy Wound Manage 2010;56:36-44.

71 Kiritsy CP, Lynch AB, Lynch SE: Role of growth factors in cutaneous wound healing: a review. Crit Rev Oral Biol Med 1993;4:729-760.

72 Pananas N, Maltezos E: Growth factors in the treatment of diabetic foot ulcers: new technologies, any promises? Int J Low Extrem Wounds 2007;6:37-53.

73 Pierce GF, Tarpley JE, Tsegn J, Bready J, Chang D, Kenney WC, Rudolph R, Robson MC, Vande Berg J, Reid P et al.: Detection of platelet-derived growth factor (PDGF)-AA in actively healing human wounds treated with recombinant PDGF-BB and absence of PDGF in chronic nonhealing wounds. J Clin Invest 1995;96:13361350.

-74 Brown RL, Breeden MP, Greenhalgh DG: PDGF and TGF-alpha act synergistically to improve wound-healing in the genetically diabetic mouse. J Surg Res 1993;56:562-570. 


\section{Cellular Physiology Cell Physiol Biochem 2015;36:1-23 \begin{tabular}{l|l|l}
\hline DOI: 10.1159/000374049 & C 2015 S. Karger AG, Basel
\end{tabular} www.karger.com/cpb \\ Borena et al.: Regenerative Cutaneous Wound Therapies}

75 Leahy PJ, Lawrence WT: Biologic enhancement of wound healing. Clin Plast Surg 2007;34:659-671.

76 Demidova-Rice TN, Hamblin MR, Herman IM: Acute and impired wound healing: pathophysiology and current methods for drug delivery, part 2: role of growth factors in normal and pathological wound healing: therapeutic potential and methods of delivery. Adv Skin Wound Care 2012;25:349-370.

77 Tomic-Canic M, Ayello EA, Stojadinovic 0, Golinko MS, Brem H: Using gene transcription patterns (bar coding scans) to guide wound debridement and healing. Adv Skin Wound Care 2008;21:487-492.

78 Hinchliffe RJ, Valk GD, Apelqvist J, Armstrong DF, Bakker K, Game FL, Hartemann-Heurtier A, Londahl M, Prince PE, van Houtum WH, Jeffcoate WJ: A systematic review of the effectiveness of interventions to enhance the healing of chronic ulcers of the foot in diabetes. Diabetes Metab Res Rev 2008;24:S119-144.

79 Beenken A, Mohammadi M: The FGF family: biology, pathophysiology and therapy. Nat Rev Drug Discov 2009;8:235-253.

-80 Allen Jr RJ, Soares MA, Haberman ID, Szpalski C, Schachar J, Lin CD, Nquyen PD, Saadeh PB, Warren SM: Combination therapy accelerates diabetic wound closure. PloS One 2014;9:e92667.

81 Barrientos S, Stojadinovic 0, Golinko MS, Brem H and Tomic-Canic M: Growth factors and cytokines in wound healing. Wound Repair Regen 2008;16:585-601.

82 Xie J, Bian H, Qi S, Xu Y, Tang J, Li T, Liu X: Effects of basic fibroblast growth factor on the expression of extracellular matrix and matrix metalloproteinase-1 in wound healing. Clin Exp Dermatol 2008;33:176182.

83 Niu J, Chang Z, Peng B, Xia Q Lu W, Huanq P, Tsao MS, Chiao PJ: Keratinocyte growth factor/fibroblast growth factor-7 regulated cell migration and invasion through activation of NF-kappaB transcription factors. J Biol Chem 2007;282:6001-6011.

84 Komi-Kuramochi A, Kawano M, Oda Y, Asada M, Suzuki M, Oki J, Imamura T: Expression of fibroblast growth factors and their receptors during full-thickness skin wound healing in young and aged mice. J Endocrinol 2005;186:273-289.

-85 Bing M, Da-Sheng C, Zhao-Fan X, Dao-Feng B, Wei L, Zhi-Fang C, Qiang W, Jia H, Jia-Ke C, Chuan-An S, YongHua S, Guo-An Z, Xiao-Hua H: Randomized, multicenter, double-blind, and placebo-controlled trial using topical recombinant human acidic fibroblast growth factor for deep partial-thickness burns and skin graft donor site. Wound Repir Regen 2007;15:795-799.

-86 Tsuboi R, Rifkin DB: Recombinant basic fibroblast growth factor stimulates wound healing in healingimpaired db/db mice. J Exp Med 1990;172:245-251.

87 Shi HX, Lin C, Lin BB, Wang ZG, Zhang HY, Wu FZ, Cheng Y, Xiang LJ, Guo DJ, Luo X, Zhang GY, Fu XB, Bellusci S, Li XK, Xiao J: The anti-scar effects of basic fibroblast growth factor on the wound repair in vitro and in vivo. PLoS One 2013;8:e59966.

88 Robson MC, Phillips TJ, Falanga V, Odenheimer DJ, Parish CL, Jesen JL, Steed DL: Randomized trial of topically applied repifermin (recombinant human keratinocyte growth factor-2) to accelerate wound healing in venous ulcers. Wound Repair Regen 2001;9:347-352.

-89 Ma B, Cheng D, Xia ZF, Ben DF, Lu W, Cao ZF, Wang Q, He J, Chai JK, Shen CA, Sun YH, Zhang GA, Hu XH: Randomized, multicenter, double-blind, and placebo-controlled trial using topical recombinant human acidic fibroblast growth factor for deep partial-thickness burns and skin graft donor site. Wound Repair Regen 2007;15:795-799.

-90 Cromack DT, Pierce GF, Mustoe TA: TGF-beta and PDGF mediated tissue repair: identifying mechanisms of action using impaired and normal models of wound healing. Prog Clin Biol Res 1991;365:359-373.

-91 Finnson KW, Arany PR, Philip A: Transforming growth factor beta signaling in cutaneous wound healing: lessons learned from animal studies. Adv Wound Care (New Rochelle) 2012;2:225-237.

92 Saha M, Foreman DM, Ferguson MW: Neutralising antibody to TGF-beta 1,2 reduces cutaneous scarring in adult rodents. J Cell Sci 1994;107:1137-1157.

-93 Saha M, Foreman DM, Ferguson MW: Neutralisation of TGF-beta1 and TGF-beta 2 or exogenous addition of TGF-beta 3 to cutaneous rat wounds reduces scarring. J Cell Sci 1995;108:985-1002.

-94 So K, McGrouther DA, Bush JA, Durani P, Taylor L, Skotny G, Mason T, Metcalfe A, O’Kane S, Ferguson MW: Avotermin for scar improvement following scar revision surgery: a randomized, double-blind, withinpatient, placebo-controlled, phase II clinical trial. Plast Reconstr Surg 2011;128:163-172.

95 McCollum PT, Bush JA, James G, Mason T, O’Kane S, McCollum C, Krievins D, Shiralkar S, Ferguson MW: Randomized phase II clinical trial of avotermin versus placebo for scar improvement. Br J Surg 2011;98:925-934. 


\section{Cellular Physiology Cell Physiol Biochem 2015;36:1-23 \begin{tabular}{l|l} 
and Biochemistry Published onlıne: April 27, 2015 & $\begin{array}{l}\text { C 2015 S. Karger AG, Basel } \\
\text { www.karger.com/cpb }\end{array}$ \\
\hline
\end{tabular} \\ Borena et al.: Regenerative Cutaneous Wound Therapies}

-96 Occleston NL, O’Kane S, Laverty HG, Cooper M, Fairlamb D, Mason T, Bush JA, Ferguson MW: Discovery and development of avotermin (recombinant human transforming growth factor beta 3): a new class of prophylactic therapeutic for the improvement of scarring. Wound Repair Regen 2011;19:e38-48.

97 Galiano RD, Tepper OM, Gurtne GC: Topical vascular endothelial growth factor accelerates diabetic wound healing through increased angiogenesis and by mobilizing and recruiting bone marrow-derived cells. Am J Pathol 2004;164:1935-1947.

-98 Delgado AV, McManus AT, Chambers JP: Exogenous administration of Substance P enhances wound healing in a novel skin-injury model. Exp Biol Med (Maywood) 2005;230:271-280.

-99 Brem H, Kodra A, Golinko MS, Entero H, Stojadinovic O, Wang VM, Sheahan CM, Weinberg AD, Woo SLC, Ehrich HP, Tomic-Canic M: Mechanism of sustained release of vascular endothelial growth factor in accelerating experimental diabetic healing. J Invest Dermatol 2009; dio:10.1038/jid.

100 Tan Q Chen B, Yan X, Lin Y, Xiao Z, Hou X, Dai J: Promotion of diabetic wound healing by collagen scaffold with collagen-binding vascular endothelial growth factor in a diabetic rat model. J Tissue Eng Regen Med 2014;8:195-201.

101 Hanft JR, Pollak RA, Barbul A, van Gils C, Kwon PS, Gray SM, Lynch CJ, Semba CP, Breen TJ: Phase I trial on the safety of topical rhVEGF on chronic neuropathic diabetic foot ulcers. J Wound Care 2008;17:30-37.

102 Girdler NM, McGurk M, Aqual S, Prince M: The effect of epidermal growth factor mouth wash on cytotoxic induced oral ulceration. A phase I clinical trial. Am J Clin Oncol 1995;18:403-406.

103 Barrandon Y, Green H: Cell migration is essential for sustained growth of keratinocyte colonies: the roles of transforming growth factor-alpha and epidermal growth factor. Cell 1987;50:1131-1137.

104 Schultz GS, Rotatori SD, Clark W: EGF and TGF $\beta$ in wound healing and repair. J Cell Biochem 1991;45:346352.

105 Brown GL, Nanney LB, Griffen J, Gramer AB, Yancey JM, Curtsinger LJ, Holtzin L, Schultz GS, Jurkiewicz MJ, Lynch JB: Enhancement of wound healing by topical treatment with epidermal growth factor. N Engl J Med 1989;321:76-79.

106 Kim YS, Lew DH, Tark KC, Rah DK, Hong JP: Effect of recombinant human epidermal growth factor against cutaneous scar formation in murine full-thickness wound healing. J Korean Med Sci 2010;25:589-596.

107 Lee JH, Bae IH, Choi JK, Part JW: Evaluation of a highly skin permeable low-molecular-weight protamine conjugated epidermal growth factor for novel burn wound healing therapy. J Pharm Sci 2013;102:41094120.

108 Brown GL, Curtsinger L, Jurkiewics MJ, Nahai F, Schultz G: Stimulation of healing of chronic wounds by epidermal growth factor. Plast Reconstr Surg 1991;88:189-194.

109 Oldooz A, kumar N, Amirali RS: Therapeutic effects of human epidermal growth factor. Res J Biotechnol 2013;8:77-80.

110 Haase I, Evans R, Pofahi R, Watt FM: Regulation of keratinocyte shape, migration and wound epithelialization by IGF-1 and EGF-dependent signaling pathways. J Cell Sci 2003;15:3227-3238.

111 Yu DH, Mace KA, Hansen SL, Boudreau N, Young DM: Effects of decreased insulin-like growth factor-1 stimulation of hypoxia inducible factor $1-\alpha$ protein synthesis and function during cutaneous repair in diabetic mice. Wound Repair Regen 2007;15:628-635.

112 Tsuboi R, Shi CM, Sato C, Cox GN, Ogawa H: Co-administration of insulin-like growth factor (IGF)-I and IGFbinding protein-1 stimulates wound healing in animal models. J Invest Dermatol 1995;104:199-203.

113 Brown DL, Kane CD, Chernausek SD, Greenhalgh DG: Differential expression and localization of insulin-like growth factors I and II in cutaneous wounds of diabetic and non-diabetic mice. Am J Pathol 1997;151:715724.

114 Greenhalgh DG, Hummel RP, Albertson S, Breeden MP: Synergistic actions of platelet-derived growth factor and the insulin-like growth factors in vivo. Wound Repair Regen 1993;1:69-81.

115 Matsumoto K, Nakamura T: Hepatocyte growth factor (HGF) as a tissue organizer for organogenesis and regeneration. Biochem Biophys Res Commun 1997;239:639-644.

116 Conway K, Price P, Harding KG, Jiang WG: The molecular and clinical impact of hepatocyte growth factor, its receptor, activators, and inhibitors in wound healing. Wound Repair Regen 2006;14:2-10.

-117 Yoshida S, Yamaguchi Y, Itami S, Yoshikawa K, Tabata Y, Matsumoto K, Nakamura T: Neutralization of hepatocyte growth factor leads to retarded cutaneous wound healing associated with decreased neovascularization and granulation tissue formation. J Invest Dermatol 2003;120:335-343. 


\section{Cellular Physiology Cell Physiol Biochem 2015;36:1-23 \begin{tabular}{l|l|l}
\hline DOI: 10.1159/000374049 & (C) 2015 S. Karger AG, Basel
\end{tabular} www.karger.com/cpb \\ Borena et al.: Regenerative Cutaneous Wound Therapies}

118 Li J, Duan H, Wu C, Zhang D, Deng Y, Yin H, Han B, Gong H, Wang H, Wang Y: HGF accelerates wound healing by promoting the dedifferentiation of epidermal cells through $\beta 1$-integrin/ILK pathway. Biomed Res Int 2013;470418.

119 Andree C, Swain WF, Page CP, Macklin MD, Slama J, Hatzis D, Eriksson E: In vivo transfer and expression of a human epidermal growth factor gene accelerates wound repair. Proc Natl Acad Sci (USA) 1994;91:12188-12192.

120 Chen FM, Zhang M, Wu ZF: Toward delivery of multiple growth factors in tissue engineering. Biomaterials 2010;31:6279-6308.

121 Bodnar RJ: Epidermal growth factor and epidermal growth factor receptor: The Yin and Yang in the treatment of cutaneous wounds and cancer. Adv Wound Care (New Rochelle) 2013;2:24-29.

122 Vasquez R, Marien BJ, Gram C, Goodwin DG, Menzoian JO, Raffetto JD: Proliferative capacity of venous ulcer wound fibroblasts in the presence of platelet-derived growth factor. Vasc Endovascular Surg 2004;38:355360.

123 Lee K, Silva EA, Mooney DJ: Growth factor delivery-based tissue engineering: general approaches and a review of recent developmnents. J R Soc Interface 2011;8:153-170.

124 Martin P: Wound healing: aiming for perfect skin regeneration. Science 1997;276:75-81.

125 Young A, McNaught CE: The physiology of wound healing. Surgery 2011;29:475-479.

126 George B: Regulations and guidelines governing stem cell based products: Clinical considerations. Perspect Clin Res 2011;2: 94-99.

127 Bell L, Devaney S: Gaps and overlaps: Improving the current regulation of stem cells in the UK. J Med Ethics 2007;33:621-622.

128 Fortier LA: Stem cell: classification, controversies and clinical application. Vet Surg 2005;34:415-423.

129 Bongso A, Richards M: History and perspectives of stem cell research; in Fisk N, Itskovitz J (eds): Best Practice and Research Clinical Obstetrics and Gynaecology. London, Elsevier Ltd 2004.

130 Bongso A, Lee EH: Stem cells. World scientific publisher 2005, pp. 1-533.

131 Volk SW, Theoret C: Translating stem cells therapies: the role of companion animals in regenerative medicine. Wound Repair Regen 2012;21:382-394.

132 Lau K, Paus R, Tiede S, Day P, Bayat A: Exploring the role of stem cells in cutaneous wound healing. Exp Dermatol 2009;18:921-933.

133 Tamama K, Kerpedjieva SS: Acceleration of wound healing by multiple growth factors and cytokines secreted from multipotential stromal cells/mesenchymal stem cells. Adv Wound Care 2012;1:177-182.

134 Richardson LE, Dudhia J, Clegg PD, Smith R: Stem cells in veterinary medicine-attempts at regenerating equine tendon after injury. Trends Biotechnol 2007;25:409-416.

135 Fox DB, Warnock JJ, Stoker AM, Luther JK, Cockrell M: Effect of growth factors on equine synovial fibroblasts seeded on synthetic scaffolds for avascular meniscal tissue engineering. Res Vet Sci 2010;88:326-332.

136 Krampera M, Pizzolo G, Aprili G, Franchini M: Mesenchymal stem cells for bone, cartilage, tendon and skeletal muscle repair. Bone 2006;39:678-683.

137 Aggarwal S, Pittenger MF: Human mesenchymal stem cells modulate allogenic immune cell response. Blood 2005;105:1815-1822.

138 Kim JW, Lee JH, Lyoo YS, Jung DJ, Park HM: Effect of topical mesenchymal stem cell transplantation in canine experimental cutaneous wounds. Vet Dermatol 2013;24:242-e53.

139 Wu Y, Chen L, Scott PG and Tredget EE: Mesenchymal stem cells enhance wound healing through differentiation and angiogenesis. Stem cells 2007;25:2648-2659.

140 Mei SH, Haitsma JJ, Dos Santos CC, Deny Y, Lai, PF Slutsky AS, Liles WC, Stewart DJ: Mesenchymal stem cells reduce inflammation while enhancing bacterial clearance and improving survival in sepsis. Am J Respir Crit Care Med 2010;182:1047-1057.

141 Krasnodembskaya A, Song Y, Fang X, Gupta N, Serikov V, Lee JW, Matthay MA: Antibacterial effect of human Mesenchymal stem cells is mediated in part from secretion of the antimicrobial peptide LL-37. Stem cells 2010;28:2229-2238.

142 Shumakov VI, Onishchenov NA, Rasulov MF, Krasheninnikov ME, Zaidenov VA: Mesenchymal bone marrow stem cells more effectively stimulate regeneration of deep burn wounds than embryonic fibroblasts. Bull Expt Biol Med 2003;136:192-195. 


\section{Cellular Physiology Cell Physiol Biochem 2015;36:1-23 \begin{tabular}{l|l} 
and Biochemistry Publisned ontIne: AprII 27, 2015 & $\begin{array}{l}\text { C 2015 S. Karger AG, Basel } \\
\text { www.karger.com/cpb }\end{array}$ \\
\hline
\end{tabular}

143 Nakagawa H, Akita S, Fukui M, Fujii T, Akino K: Human mesenchymal stem cels successfully improve skin substitute wound healing. Br J Dermatol 2005;153:29-36.

144 McFarlin K, Gao X, Liu YB, Dulchavsky DS, Kwon D, Arbab AS, Bansal M, Li Y, Chopp M, Dulchavsky SA, Gautam SC: Bone marrow-derived mesenchymal stromal cells accelerate wound healing in the rat. Wound Repair Regen 2006;14:471-478.

145 Stoff A, Rivera AA, Sanjib NB, Moore ST, Michael NT, Espinosa-de-Los-Monteros A, Richter DF, Siegal GP, Chow LT, Feldman D, Vasconez LO, Michael Mathis J, Stoff-Khalili MA, Curiel DT: Promotion of incisional wound repair by human mesenchymal stem cell transplantation. Exp Dermatol 2009;18:362-369.

146 Sasaki M, Abe R, Fujita Y, Ando S, Inokuma D, Shimizu H: Mesenchymal stem cells are recruited into wounded skin and contribute to wound repair by transdifferentiation into multiple skin cell types. J Immunol 2008;180:2581-2587.

147 Tamai K, Yamazaki T, Chino T, Ishii M, Otsurus S, Kikuchi Y, Linuma S, Saga K, Nimura K, Shimbo T, Umegaki N, Katayama I, Miyazaki J, Takeda J, McGrath JA, Uitto J, Kaneda Y: PDGFRalpha-positive cells in bone marrow are mobilized by high mobility group box 1(HMGB 1) to regenerate injured epithelia. Proc Natl Acad Sci (USA) 2011;108:6609-6614.

148 Azari O, Babaei H, Derakhshanfar A, Nematollahi-Mahani S, Poursahebi R, Moshrefi M: Effects of Transplanted mesenchymal cells isolated from wharton's jelly of caprine umbilical cord on cutaneous wound healing: histopathological evaluation. Vet Res Commun 2011;35:211-222.

-149 Pratheesh MD, Gade NE, Dubey PK, Nath A, Sivanaravanan TB, Madhu DM, Sharma B, Amarpal, Saikumar G, Sharma GT: Molecular characterization and xenogenic application of Warton's jelly derived caprine mesenchymal stem cells. Vet Res Commun 2014;38:139-148.

150 Spaas JH, Broeckx S, Van de Walle GR, Polettini M: The effects of equine peripheral blood stem cells on cutaneous wound healing: a clinical evaluation in four horses. Clin Exp Dermatol 2013;38:280-284.

151 Vojtassák J, Danisovic L, Kubes M, Bakos D, Jarábek L, Ulicná M, Blasko M: Autologous biograft and mesenchymal stem cells in treatment of the diabetic foot. Neuro Endocrinol Lett 2006;27:134-137.

152 Falanga V, Iwamoto S, Chartier M, Yufit T, Butmarc J, Kouttab N, Shrayer D, Carson P: Autologous bone marrow-derived cultured mesenchymal stem cells delivered in a fibrin spray accelerate healing in murine and human cutaneous wounds. Tissue Eng 2007;13:1299-1312.

153 Dash NR, Dash SN, Routray P, Mohapatra S, Mohapatra PC: Targeting nonhealing ulcers of lower extremity in human through autologous bone marrow-derived mesenchymal stem cells. Rejuvenation Res 2009;12:359-366.

154 Jain P, Perakath B, Jesudason MR, Nayak S: The effect of autologous bone marrow-derived cells on healing chronic lower extremity wounds: results of a randomized controlled study. Ostomy Wound Manage 2011;57:38-44.

155 Lu D, Chen B, Liang Z, Deng W, Jiang Y, Li S, Xu J, Wu Q, Zhang Z, Xie B, Chen S: Comparison of bone marrow mesenchymal stem cells with bone marrow-derived mononuclear cells for treatment of diabetic critical limb ischemia and foot ulcer: a double-blind randomized, controlled trial. Diabetes Res Clin Pract 2011;92:26-36.

156 Kondo M, Wagers AJ, Manz MJ, Prohaska SS, Scherer DC, Beihack GF, shizuru JA, Weissman IL: Biology of hematopietic stem cells and proginators: implication for the clinical application. Annu Rev Immunol 2003;21:759-806.

157 Krause DS, Theise ND, Collector MI, Henegariu O, Hwang S, Gardner R, Neutzel S, Sharkis SJ: Multi-organ, multi-lineage engraftment by a single bone marrow-derived cell. Cell 2001;105:369-377.

158 Chan RK, Garfein E, Giqante PR, Liu P, Aqha RA, Mulliqan R, Orqill DP: Side population hematopoietic stem cells promote wound healing in diabetic mice. Plast Reconstr Surg 2007;120:407-411.

159 Plikus MV, Gay DL, Treffeisen E, Wang A, Supapannachart RJ: Epithelial stem cells and implications for wound repair. Seminars in Cell and Developmental Biology 2012;23:946-953.

160 Yang X, Qu L, Wang X, Zhao M, Li W, Hua J, Shi M, Moldovan N, Wang H, Dou Z: Plasticity of epidermal adult stem cells derived from adult goat ear skin. Mol Reprod Dev. 2007;74:386-396.

161 Zuk PA, Zhu M, Ashjian P, De Ugarte DA, Huang JI, Mizuno H, Alfonso ZC, Fraser JK, Benhaim P, Hedrick MH: Human adipose tissue is a source of multipotent stem cells. Mol Biol Cell 2002;13:4279-4295.

162 Izadpanah R, Trygg C, Patel B, Kriedt C, Dufour J, Gimble JM, Bunnell BA: Biologic properties of mesenchymal stem cells derived from bone marrow and adipose tissue. J Cell Biochem 2006;99:12851297. 


\section{Cellular Physiology Cell Physiol Biochem 2015;36:1-23 \begin{tabular}{l|l} 
and Biochemistry Published online: April 27, 2015 & $\begin{array}{l}\text { C) 2015 S. Karger AG, Basel } \\
\text { www.karger.com/cpb }\end{array}$
\end{tabular}}

163 Lee SH, Jin SY, Song JS, Seo KK, Cho KH: Paracrine effects of adipose derived stem cells on keratinocyte and dermal fibroblasts. Ann Dermatol 2012;24:136-143.

164 Lee SH, Lee JH, Cho KH: Effects of human adipose-derived stem cells on cutaneous wound healing in nude mice. Ann Dermatol 2011;23:150-155.

-165 Blasi A, Martino C, Balducci L, Saldarelli M, Soleti A, Navone SE, Canzi L, Cristini S, Invernici G, Parati EA, Alessandri G: Dermal fibroblasts display similar phenotypic and differentiation capacity to fat-derived mesenchymal stem cells, but differ in anti-inflammatory and angiogenic potential. Vascular Cell 2011;3:514.

166 You HJ, Han SK: Cell therapy for wound healing. J Korean Med Sci 2014;29:311-319.

167 Bello YM, Falabella AF, Eaglstein WH: Tissue engineered skin. Current status in wound healing. Am J Clin Dermatol 2001;2:305-313.

168 Han YF, Tao R, Sun TJ, Chai JK, Xu G, Liu J: Advances and opportunities for stem cell research in skin tissue engineering. Eur Rev Med Pharmacol Sci 2012;16:1873-1877.

169 Michael S, Sorg H, Peck CT, Koch L, Deiwick A, Chichkov B, Vogt PM, Reimers K: Tissue engineered skin substitutes created by laser-assisted bioprinting form skin-like structures in the dorsal skin fold chamber in mice. PLoS ONE 2013;8:e57741

170 Cichowski A, Kawechi M, Glik J, Klama-Baryla A, Labus W, Maj M, Nowak M, Dworak A, Sieroń AL: Literature review concerning cell and skin substitute cultures obtained by means of tissue engineering used in the treatment of burns. Pol Przegl Chir 2014;86:202-210.

171 Mayet N, Choonara YE, Kumar P, Tomar LK, Tyagi C, Du Toit LC, Pillay V: A comprehensive review of advanced biopolymeric wound healing systems. J Pharm Sci 2014;103:2211-2230.

172 Nyame TT, Chiang HA, Orgill DP: Clinical Applications of Skin Substitutes. Surg Clin North Am 2014;94:839850.

173 Hefton JM, Caldwell D, Biozes DG, Balin AK, Carter DM: Grafting of skin ulcers with cultured autologous epidermal cells. J Am Acad Dermatol 1986;14:399-405.

174 Leigh IM, Purkis PE: Culture grafted leg ulcers. Clin Exp Dermatol 1986;11:650-652.

175 Leigh IM, Purkis PE, Navsaria HA, Phillips TJ: Treatment of chronic venous leg ulcers with sheets of cultured allogenic keratinocytes. Br J Dermatol 1987;117:591-597.

176 Spiekstra SW, Breetveld M, Rustemeyer T, Scheper RJ, Gibbs S: Wound-healing factors secreted by epidermal keratinocytes and dermal fibroblasts in skin substitutes. Wound Repair Regen 2007;15:708-717.

177 Wojtowicz AM, Oliveira S, Carlson MW, Zawadzka A, Rousseau CF, Baksh D: The importance of both fibroblasts and keratinocytes in bilayered living cellular construct used in wound healing. Wound Repair Regen 2014;22:246-255.

178 Auxenfans C, Shipkov H, Bach C, Catherine Z, Lacroix P, Bertin-Maghit M, Damour O: Cultured allogenic keratinocytes for extensive burns: a retrospective study over 15 years. Burns 2013;40:82-88.

179 Kazemi-Darabadi S, Sarrafzadeh-Rezaei F, Farshid AA, Dalir-Naghadeh B: Allogenous skin fibroblast transplantation enhances excisional wound healing following alloxan diabetic in sheep, a randomized controlled trial. Int J Surg 2014;doi: 10.1016/j.ijsu.2014.06.007.

180 Yamaguchi Y, Kubo T, Murakami T, Takhashi M, Hakamata Y, Kobayashi E, Yoshda S, Hosokowa K, Yoshikawa $\mathrm{K}$, Itami S: Bone marrow cells differentiate into wound myofibroblasts and accelerate the healing of wound with occlusive dressing. Cutaneous Biology. Br J Dermatol 2005;152:616-622.

181 Oloumi MM, Derakhshanfar A, Shemali H, Shavalian M: The role of Autogenous Bone marrow in the healing of experimental burn wound healing in rabbits. Iran J Vet Surg 2008;3:47-55.

-182 Borena BM, Pawde AM, Amarpal, Aithal HP, Kinjavdekar P, Singh R, Kumar D: Autologous bone marrowderived cells for healing excisional demal wounds of rabbits. Vet Rec 2009;165:563-568.

183 Borena BM, Pawde AM, Amarpal, Aithal HP, Kinjavdekar P, Singh R, Kumar D: Evaluation of autologous bone marrow-derived nucleated cells for healing of full thickness skin wounds in rabbits. Int Wound J 2010;7:249-260.

184 Borena BM, Pawde AM, Amarpal, Aithal HP, Kinjavdekar P, Singh R, Kumar D: Evaluation of healing potential of autologous bone marrow-derived nucleated cells on incisional wounds in dogs. Indian J Vet Surg 2009;30:85-89.

185 Badiavas EV, Falanga V: Treatment of chronic wounds with bone marrow derived cells. Arch Dermatol 2003;139:510-516. 


\section{Cellular Physiology Cell Physiol Biochem 2015;36:1-23 \begin{tabular}{l|l}
\hline DOI: 10.1159/000374049 & (c) 2015 S. Karger AG, Basel
\end{tabular}

186 Bielefeld K, Amini-Nik S, Alman BA: Cutaneous wound healing: recruiting developmental pathways for regeneration. Cell Mol Life Sci 2012;70:2059-2082.

187 Schatteman GC, Ma N: Old bone marrow cells inhibit skin wound vascularization. Stem cells 2006;24:717721.

188 Jarrold B, Date A, Osborne R: Age-dependent differences in putative epidermal stem cell activity assessed in human skin equivalents. J Invest Dermatol 2012;132:S135-S135.

$\checkmark 189$ Koch TG, Berg LC, Betts DH: Current and future regenerative medicine-principles, concepts and therapeutic use of stem cell therapy and tissue engineering in equine medicine. Can Vet J 2009;50:155-165.

190 Kuhn NZ, Tuan RS: Regulation of stemness and stem cell niche of mesenchymal stem cells: implications in tumorigenesis and metastasis. Journal of Cellular Physiology 2010;222:268-277.

191 Broeckx S, Borena BM, Zimmerman M, Mariën T, Seys B, Suls M, Duchateau L, Spaas JH: Intravenous Application of Allogenic Peripheral Blood-Derived Mesenchymal Stem Cells: a Safety Assessment in 291 Equine Recipients. Curr Stem Cell Res Ther. 2014;9:452-457.

192 Broeckx S, Zimmerman M, Crocetti S, Suls M, Marien T, Ferguson SJ, Chiers K, Duchateau L, Franco-Obregon A, Wuertz K, Spaas JH: Regenerative therapies for equine degenerative joint disease: a preliminary study. PLoS One 2014;9:e85917.

193 Carrade DD, Affolter VK, Outerbridge CA, Watson JL, Galuppo LD, Buerchler S, Kumar V, Walker NJ, Borjesson DL: Intradermal injections of equine allogeneic umbilical cord-derived mesenchymal stem cells are well tolerated and do not elicit immediate or delayed hypersensitivity reactions. Cytotherapy 2011;13:1180-1192.

194 Carrade DD, Owens SD, Galuppo LD, Vidal MA, Ferraro GL, Librach F, Buerchler S, Friedman MS, Walker NJ, Borjesson DL: Clinicopathologic findings following intra-articular injection of autologous and allogeneic placentally derived equine mesenchymal stem cells in horses. Cytotherapy 2011;13:419-430.

195 Fang BJ, Song YP, Lin QD, Zhang YL, Cao Y, Zhao RCH, Ma YF: Human adipose tissue-derived mesenchymal stromal cells as salvage therapy for treatment of severe refractory acute graft-vs.-host disease in two children. Pediatr Transplant 2007;11:814-817.

196 Ringden O, Uzunel M, Rasmusson I, Remberger M, Sundberg B, Lonnies H, Marschall HU, Dlugosz A, Szakos A, Hassan Z, Omazic B, Aschan J, Barkholt L, Le Blanc K: Mesenchymal stem cells for treatment of therapyresistant graft-versus-host disease. Transplantation 2006;81:1390-1397.

197 Riordan NH, Ichim TE, Min WP, Wang H, Solano F, Lara F, Alfaro M, Rodriguez JP, Harman RJ, Patel AN, Murphy MP, Lee RR, Minev B: Non-expanded adipose stromal vascular fraction cell therapy for multiple sclerosis. J Transl Med 2009;7:29.

198 Di Nicola M, Carlo-Stella C, Magni M, Milanesi M, Longoni PD, Matteucci P, Grisanti S, Gianni AM: Human bone marrow stromal cells suppress T-lymphocyte proliferation induced by cellular or nonspecific mitogenic stimuli. Blood 2002;99:3838-3843.

199 Djouad F, Charbonnier LM, Bouffi C, Louis-Plence P, Bony C, Apparailly F, Cantos C, Jorgensen C, Noel D: Mesenchymal stem cells inhibit the differentiation of dendritic cells through an interleukin-6-dependent mechanism. Stem Cells 2007;25:2025-2032.

-200 English K, Barry FP, Mahon BP: Murine mesenchymal stem cells suppress dendritic cell migration, maturation and antigen presentation. Immunol Lett 2008;115:50-58.

201 Nasef A, Chapel A, Mazurier C, Bouchet S, Lopez M, Mathieu N, Sensebe L, Zhang YZ, Gorin NC, Thierry D, Fouillard L: Identification of IL-10 and TGF-beta transcripts involved in the inhibition of T-lymphocyte proliferation during cell contact with human mesenchymal stem cells. Gene Expr 2007;13:217-226.

202 Ortiz LA, Dutreil M, Fattman C, Pandey AC, Torres G, Go K, Phinney DG: Interleukin 1 receptor antagonist mediates the antiinflammatory and antifibrotic effect of mesenchymal stem cells during lung injury. Proc Natl Acad Sci USA 2007;104:11002-11007.

203 Corcione A, Benvenuto F, Ferretti E, Giunti D, Cappiello V, Cazzanti F, Risso M, Gualandi F, Mancardi GL, Pistoia V, Uccelli A: Human mesenchymal stem cells modulate B-cell functions. Blood 2006;107:367-372. 